\title{
Reaction of polyamines with diethyloxalate: a convenient route for the synthesis of tetraazacycloalkanes
}

\author{
Franck Denat, Raphaël Tripier, Frédéric Boschetti, Enrique Espinosa, and Roger Guilard* \\ Laboratoire d'Ingénierie Moléculaire pour la Séparation et les Applications des Gaz, LIMSAG \\ UMR 5633, Faculté des Sciences Gabriel, 6 Bvd Gabriel, 21000 Dijon, France \\ E-mail: Roger.Guilard@u-bourgogne.fr
}

Dedicated to Professor Armand Lattes on his $50^{\text {th }}$ years teaching and research

\begin{abstract}
The reactivity of various polyamines with diethyloxalate has been investigated. It appears that, in similar experimental conditions, primary diamines give predominantly [2+2] adducts while the use of secondary benzylated polyamines results in [1+1] condensation. Although the intermediate tetraamides formed in the first case are extremely poorly soluble and show very slow reactivity towards reducing agents, cyclam has been obtained by using ultrasounds during the reaction of the corresponding tetraoxomacrocycle with $\mathrm{BH}_{3} / \mathrm{THF}$. The [1+1] cyclization reaction of diversely $N$-benzylated linear tetraamines, whose selective syntheses have been devised herein, gives access to various $N$-benzylated cyclens and cyclams. New macrocyclic ligands containing both amine and amide type nitrogen atoms have been formed as intermediates in these syntheses. Two compounds containing an aminal function exhibit an unexpected reactivity, leading to the formation of new bisaminal products whose structures have been established by X-ray diffraction.
\end{abstract}

Keywords: Diethyloxalate, polyamines, tetraazacycloalkanes, aminal, reduction, selective benzylation

\section{Introduction}

The chemistry of tetraazacycloalkanes, especially cyclen and cyclam, has undergone a considerable development in the last thirty years, owing to their coordination properties. Indeed, these macrocyclic polyamines are able to form stable complexes with transition metals as well as lanthanides, actinides, and other heavy metals. ${ }^{1}$ The affinity and selectivity towards the metal ion can be tuned by varying the size of the macrocyclic core as well as the nature and the number of pendant coordinating arms on the nitrogen atoms. Since the first syntheses of cyclen and cyclam 
in the early 70's, there has been a still growing interest in the search of more convenient approaches for the preparation of these tetraazacycloalkanes and their derivatives. This interest is due to the usefulness of these macrocycles in many different fields including removal of metals from liquids, ${ }^{2}$ purification of gases, ${ }^{3}$ catalysis, ${ }^{4}$ sensors and probes, ${ }^{5}$ as well as medical applications. $^{6}$

Particular efforts have been devoted to the preparation of selectively functionalized tetraazacycloalkanes and the so-called bifunctional chelating agents, containing two kinds of functional groups, one for the coordination of the metal, the other one for binding the macrocycle to a macromolecule such as an antibody, or onto a solid support. ${ }^{7}$

Many methods have been devised for the synthesis of cyclen, cyclam, and their functionalized derivatives, including high dilution techniques, use of metal cations as template, protection/deprotection sequences, functionalization on either nitrogen or carbon atoms. A recent key step in this chemistry is the use of bisaminal intermediates, both for the synthesis of cyclen or cyclam and their $N$ - and/or $C$-functionalized derivatives. ${ }^{8}$ A few years ago, we have shown that the condensation of linear tetraamines with diethyloxalate in the appropriate conditions (solvent, concentration, temperature) yields mainly the [2+2] adduct, thus providing a very convenient route towards large polyazamacrocycles after reduction of the tetraamide intermediates (Scheme 1). ${ }^{9}$ Similar results have been recently reported by others. ${ }^{10}$
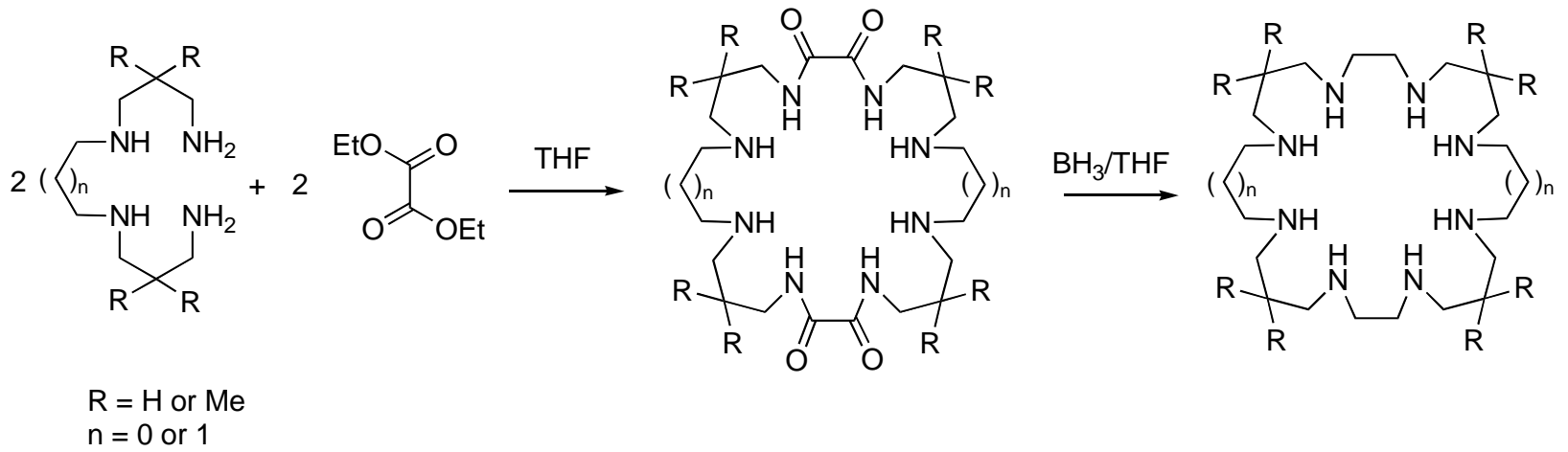

\section{Scheme 1}

As a part of our program for the development of convenient methods for the synthesis of tetraazacycloalkanes derivatives, we have investigated the reaction of diethyloxalate with diamines and $N$-benzylated polyamines. ${ }^{11}$ The main results are reported herein.

\section{Results and Discussion}

We have firstly investigated the condensation of diethyloxalate with two diamines, ethylenediamine and 1,3-propanediamine, in the conditions described in our previous paper 
(Scheme 2). The expected cyclic tetraamide intermediates $\mathbf{1 a}$ and $\mathbf{1 b}$ are extremely poorly soluble in both organic solvents and water, therefore we were not able to isolate, purify and characterize these compounds. However, infra-red data show the presence of amide type carbonyl groups at $1670 \mathrm{~cm}^{-1}$, indicating that the cyclization reaction occurs. First attempts to reduce these compounds with borane in THF failed. A strong intra- and/or inter-molecular hydrogen bonds network is probably responsible for both the insolubility of these compounds and their exceptional reluctance towards reduction. Reduction of intermediate $\mathbf{1 b}$ was finally performed by using ultrasounds, which probably break hydrogen bonds and therefore facilitate the reduction reaction. A solution of $\mathbf{1 b}$ and 1.5 equivalent of $\mathrm{BH}_{3}$ in THF was stirred for 3 hours at room temperature under sonication $(750$ watts, $20 \mathrm{KHz})$. After acidic treatment, $\mathrm{NaOH}$ was added and the solution was extracted with dichloromethane. The colourless oil obtained upon evaporation was taken in diethylether to give cyclam $\mathbf{2 b}$ as a white solid in $19 \%$ overall yield.

2

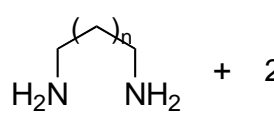

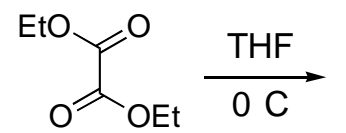

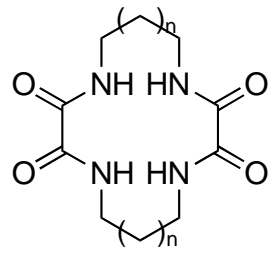

$\mathrm{n}=0,1 \mathrm{a}$

$\mathrm{n}=1, \mathbf{1 b}$

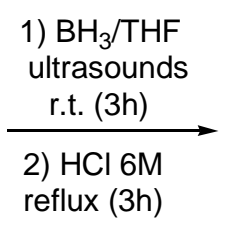

2) $\mathrm{HCl} 6 \mathrm{M}$
reflux (3h)

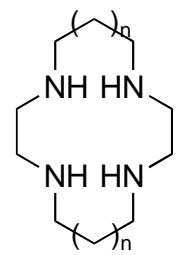

$\mathrm{n}=1, \mathbf{2 b}(22 \%)$

\section{Scheme 2}

In order to overcome the formation of a hydrogen bonds network, we have decided to use $\mathrm{N}$-benzylated diamines as starting material. Indeed, the presence of benzyl groups on nitrogen atoms should increase the lipophilic character and consequently the solubility in organic solvents. Moreover, the use of secondary amines should prevent the formation of hydrogen bonds and benzyl groups can be easily removed by catalytic hydrogenolysis. The $N, N^{\prime}-$ dibenzylated 1,3-propanediamine 4 was prepared in $80 \%$ yield by reduction of the corresponding diimine intermediate 3 obtained quantitatively by reacting 1,3-propanediamine with benzaldehyde (Scheme 3). The condensation of compound 4 with diethyloxalate, in either THF or ethanol, results in the formation of the $[1+1]$ adduct 5 , with no trace of $[2+2]$ derivative, even in relatively high concentration conditions $\left(0.08 \mathrm{~mol} \mathrm{~L}^{-1}\right)$, as shown by mass spectrometry. This diamide was easily reduced by $\mathrm{BH}_{3} / \mathrm{THF}$ to yield the dibenzylated seven-membered heterocycle 6. This experiment shows that, as expected, the reduction of benzylated polyamides is facilitated, but unfortunately secondary diamines behave differently from primary diamines when treated with diethyloxalate. The main formation of the [1+1] cyclization product also indicates that the hydrogen bonds network could be a driving force in the formation of the [2+2] adduct. This result, which has been previously described, ${ }^{12}$ prompted us to investigate the cyclization of benzylated tetraamines with diethyloxalate. 


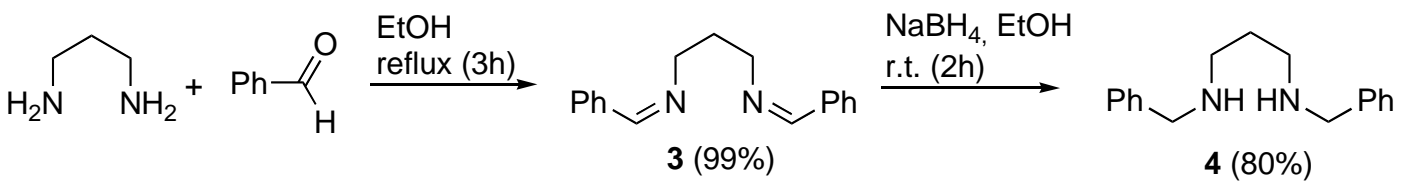

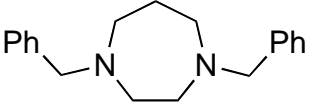

$6(97 \%)$
1) $\mathrm{BH}_{3} / \mathrm{THF}$

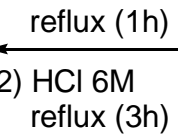

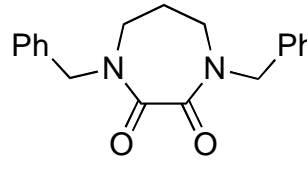

$5(83 \%)$

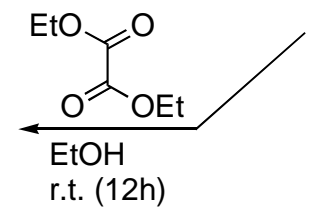

\section{Scheme 3}

Firstly, we have developed a convenient procedure for the synthesis of selectively benzylated tetraamines (Scheme 4). Some of these compounds have been reported previously. ${ }^{13}$ In the first step, the reaction of three equivalents of benzaldehyde with triethylenetetraamine and $N, N$ '-bis-(3-aminopropyl)-ethylenediamine in refluxing ethanol gives the corresponding diimine intermediates containing one aminal function $\mathbf{7 a}$ and $\mathbf{7 b}$ in very good yields (Figures 1 and 2). Depending on the subsequent treatment, these intermediates may yield the $N^{1}, N^{4}$ - or the $N^{2}, N^{3}$ dibenzylated tetraamines, or the fully benzylated compounds.

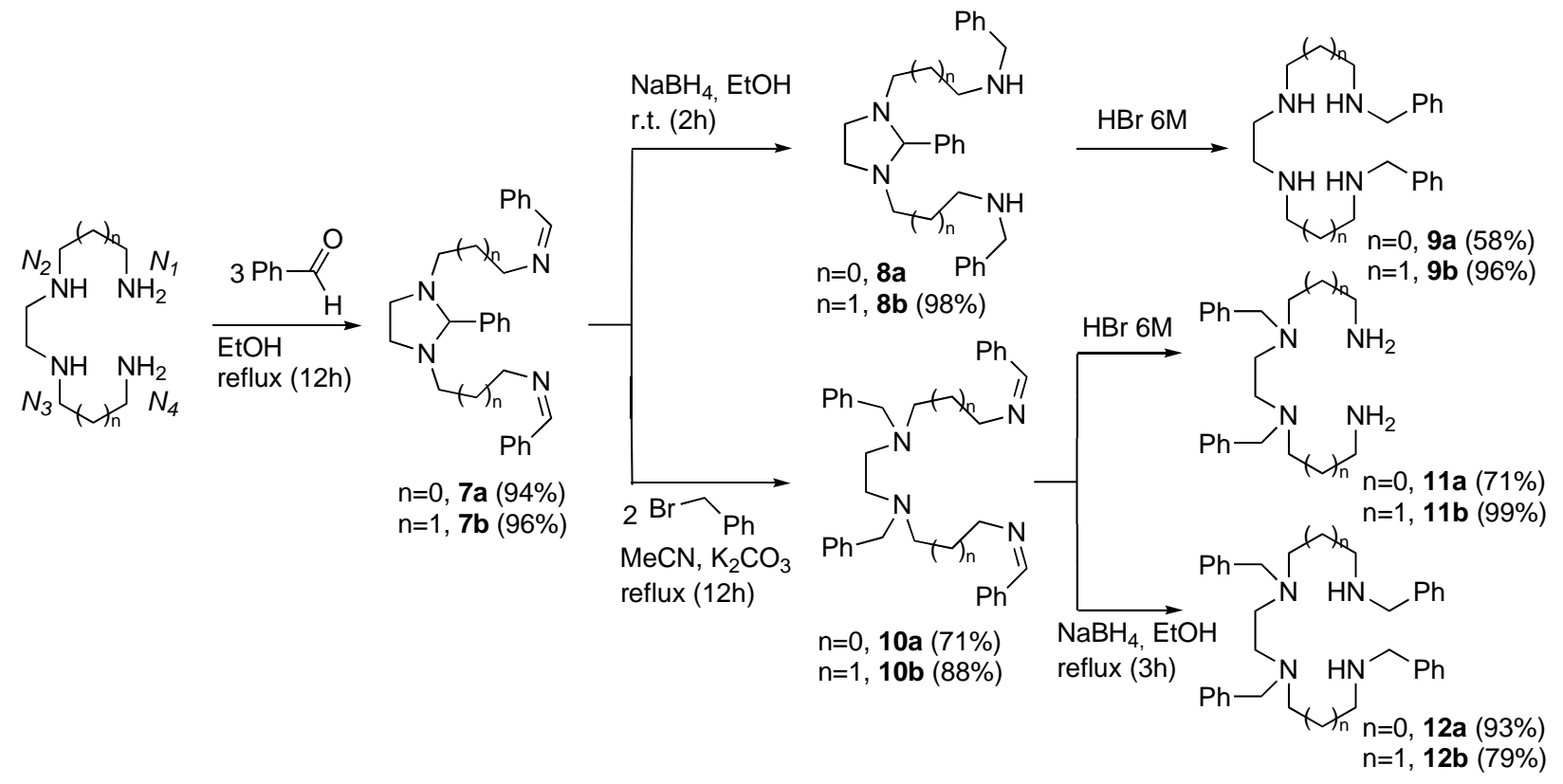

\section{Scheme 4}

The reduction of the Schiff bases 7a-b with $\mathrm{NaBH}_{4}$ in ethanol at room temperature gives the dibenzylated monoaminal compounds 8a-b. The compound 8a was not isolated because a rearrangment was observed during the work-up (vide infra). The acidic hydrolysis of 8a-b allows 
the removal of the aminal group to release the $N_{1}, N_{4}$-dibenzylated tetraamines 9a-b in good overall yields (54.5 and $90 \%$ respectively). The reaction of intermediates $7 \mathbf{a}-\mathbf{b}$ with two equivalents of benzyl bromide in refluxing acetonitrile results in the quantitative formation of the $N_{2}, N_{3}$-dibenzylated diimines 10a-b. It is noteworthy that lower yields are observed when using only one equivalent of benzyl bromide. The reaction should proceed through the nucleophilic attack of one aminal type nitrogen on one equivalent of benzyl bromide, followed by the loss of one equivalent of benzaldehyde, which can be easily detected, and finally the reaction of the resulting secondary amine with the second equivalent of benzyl bromide. The presence of water in the solvent can explain the formation of benzaldehyde. The two imine functions in 10a-b can be either hydrolysed with hydrobromic acid solution to give after neutralization and extraction the corresponding $N_{2}, N_{3}$-dibenzylated tetraamines 11a-b in 48 and $95 \%$ overall yields respectively, or reduced with $\mathrm{NaBH}_{4}$ in refluxing ethanol to yield the tetrabenzylated tetraamines 12a-b.

This methodology can be applied to different aromatic aldehydes, allowing the $N$ functionalization with other groups than the protecting benzyl groups. For instance, we have used 3-bromobenzaldehyde and 2-pyridinecarboxaldehyde to prepare difunctionalized tetraamines 15a-b (Scheme 5). The aminal group linked to a pyridine appears to be more reluctant towards hydrolysis. Indeed, the action of a $4 \mathrm{M} \mathrm{HBr}$ solution in ethanol at $0^{\circ} \mathrm{C}$, i.e. conditions used to remove the aminal group obtained with benzaldehyde and 3bromobenzaldehyde, gives a 50/50 mixture of di- and tribenzylated tetraamines 15a and 16a. However, 15a can be obtained as the sole product by refluxing the solution.

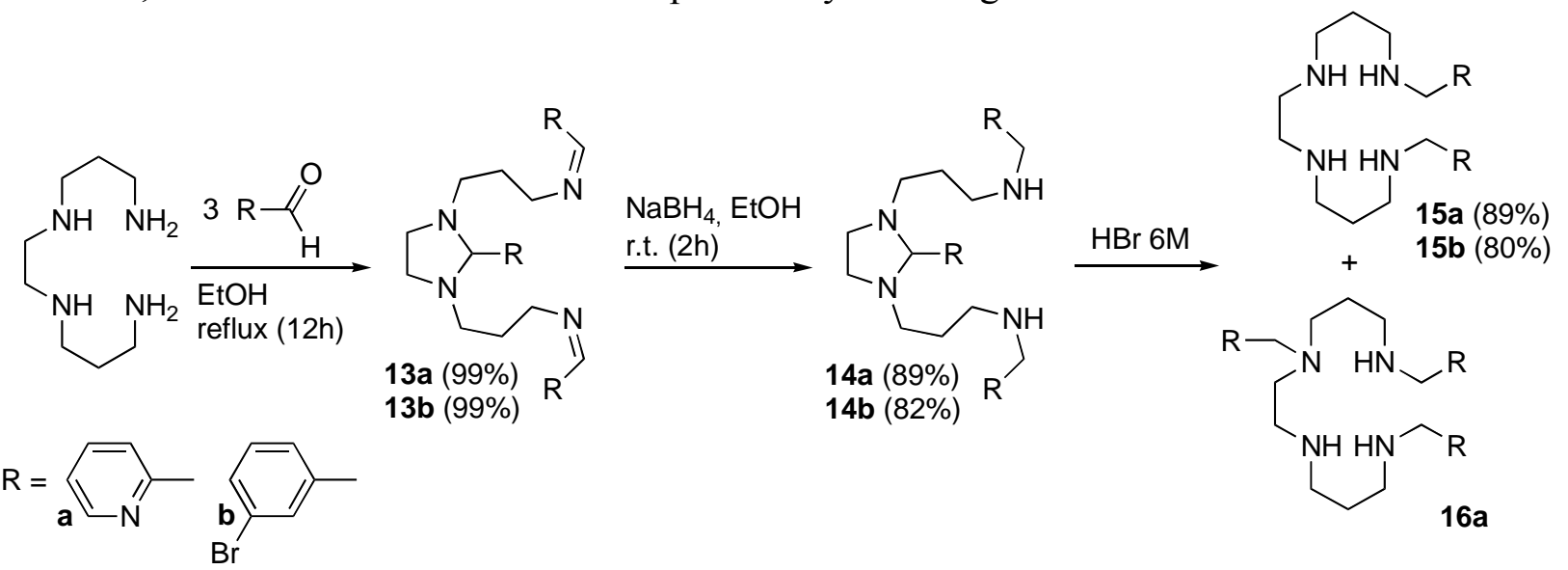

\section{Scheme 5}

The next step was to investigate the cyclization reaction of the different benzylated tetraamines with diethyloxalate. The reaction of $N_{1}, N_{4}$-dibenzylated tetraamines 9a-b with the diester in refluxing ethanol gives the aimed dioxodibenzylcyclen 18a and dioxodibenzylcyclam 18b in $20 \%$ and $30 \%$ yields respectively, after optimisation of the reaction conditions, i.e. solvent, concentration, temperature (Scheme 6, Method 1). The formation of stable six- 
membered rings is predominant and the major products are the dioxopiperazine derivatives 17ab. The ratio $\mathbf{1 7 b} / \mathbf{1 8 b}$ can be increased up to $91 / 9$ by lowering the temperature $\left(-10^{\circ} \mathrm{C}\right)$. It has to be noted that 17a was not isolated as a pure compound since for such a series the formation of a six-membered ring can lead to another isomer. The reduction of dioxomacrocycles 18a-b with borane in THF allows the synthesis of 1,4-dibenzyltetraazacycloalkanes 19a-b. The benzyl groups can be removed to give respectively cyclen $\mathbf{2 a}$ and cyclam $\mathbf{2 b}$. More interestingly, intermediates 19a and 19b are valuable precursors of macrocyclic polyamines functionalized on two adjacent nitrogen atoms when the $N$-functionalization is performed before the deprotection step. Such 1,4-difunctionalized cyclens and cyclams are difficult to prepare using known methodologies. $^{14}$

The cyclization reaction of tetrabenzylated tetraamines $\mathbf{1 2 a} \mathbf{a}-\mathbf{b}$ with diethyloxalate gives the expected dioxomacrocycles 20a and 20b in $50 \%$ and $75 \%$ yields respectively (Scheme 6, Method 2). In this case, the formation of six-membered rings does not occur due to the presence of the two tertiary amines. However, six days in refluxing ethanol were necessary to perform the cyclization reaction in good yields, thus illustrating the deactivating effect of the benzyl groups on the reactivity of the secondary amines. The reduction of compounds 20 a-b with $\mathrm{BH}_{3} / \mathrm{THF}$ leads to the tetrabenzylated cyclen and cyclam 21a-b, which can be deprotected to yield finally cyclen and cyclam.

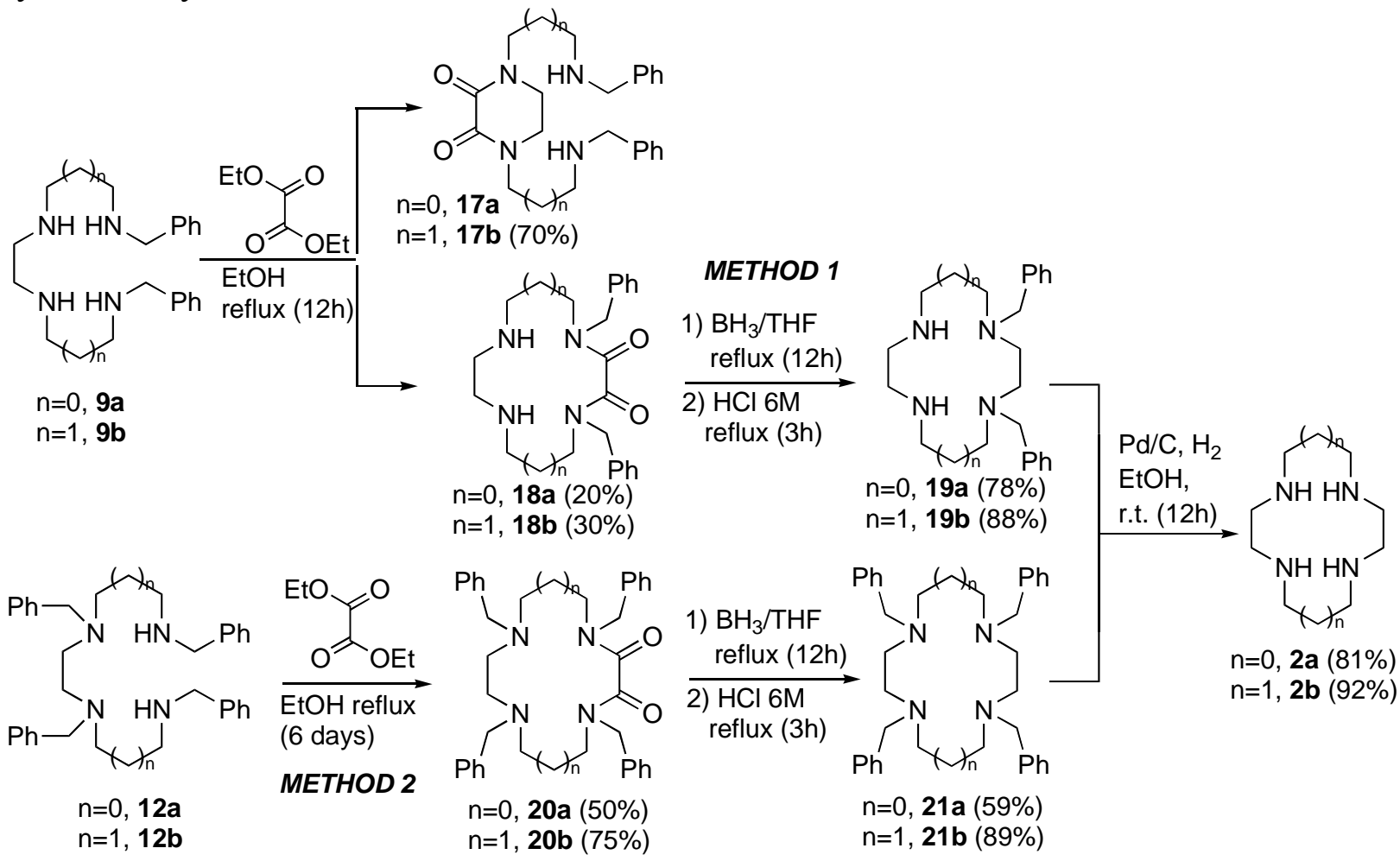

\section{Scheme 6}


Unexpected products have been obtained from the reaction of aminal diimine derivative $\mathbf{8 b}$ with diethyloxalate (Scheme 7). Indeed, this reaction does not lead to the aimed dioxoaminal macrocycle but to the rearranged product 22b (Figure 4) containing two aminal moieties, together with the dioxopiperazine derivative $\mathbf{1 7 b}$. The formation of this cyclic diamide can be explained by the initial attack of diethyloxalate on one aminal nitrogen atom, implying the loss of one equivalent of benzaldehyde, as observed in the reaction of aminal derivatives 7a-b with benzyl bromide, followed by the cyclization to yield the six-membered aminal ring. The formed benzaldehyde can then react faster than diethyloxalate with starting material $\mathbf{8 b}$, to give the bisaminal compound 22b. Due to this rearrangement, the aminal moiety cannot be used as a protecting group. The compound $\mathbf{8 a}$ behaves in a similar manner, since the bisaminal 22a (Figure 3) is obtained directly from 7a, together with the dibenzylated tetraamine 9a in a 1:1 ratio, by reduction with $\mathrm{NaBH}_{4}$ followed by hydrolysis. In this case, the intermediate 8a was not isolated, thus indicating that the formation of two five-membered rings to give 22a occurs more readily than the formation of two six-membered rings to yield 22b. The compound 22b was also obtained without using diethyloxalate, together with the dibenzylated product $\mathbf{9 b}$ in a 1:1 ratio, by refluxing $\mathbf{8 b}$ in water.
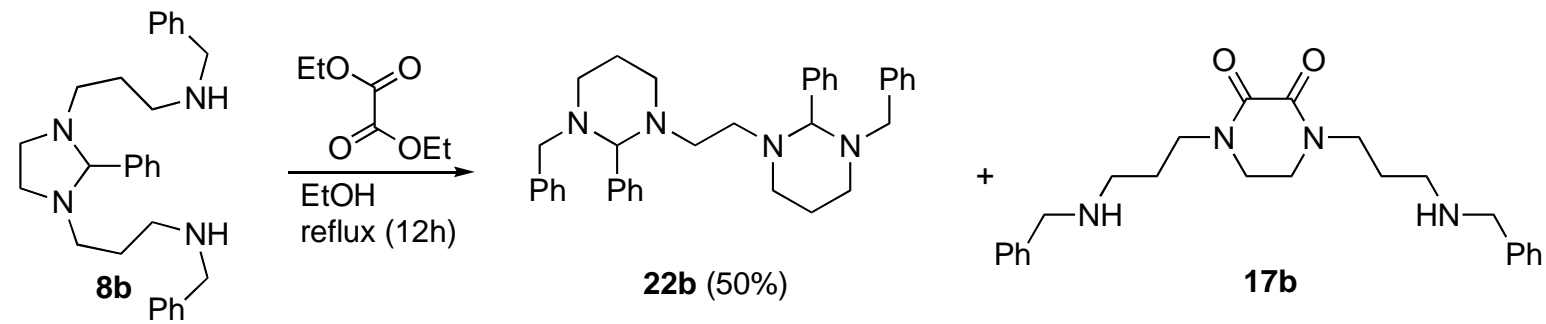

\section{Scheme 7}

It has to be noted that the reaction of one equivalent of benzaldehyde with the dibenzylated tetraamine $\mathbf{9 b}$ gives the monoaminal product $\mathbf{8 b}$, which is almost quantitatively converted to the rearranged product $\mathbf{2 2} \mathbf{b}$ by addition of a second equivalent of benzaldehyde. This experiment indicates that the rearrangement is induced by the attack of an electrophilic reagent, for instance diethyloxalate or in the latter case a second equivalent of benzaldehyde, on the tertiary nitrogen atom rather than on the terminal secondary amines. Thus, the reaction should proceed via the formation of the intermediate 23, which after nucleophilic attack of the secondary amines and loss of a water molecule, gives the bisaminal product (Scheme 8). The first step of this reaction, corresponding to the insertion of the double-bond into the C-N aminal bond is in agreement with the mecanism postulated earlier for the reaction of aminals with polarized double bonds. ${ }^{15}$ Moreover, we were able to prove the formation of such an intermediate by reacting formaldehyde with the monoaminal diimine $\mathbf{7 b}$. Indeed, the rearrangement was in this case prevented by the presence of the two imine functions, and the formation of the product resulting 
from the insertion of the carbonyl group into the $\mathrm{C}-\mathrm{N}$ aminal bond is evidenced by MALDI-TOF mass spectrometry.

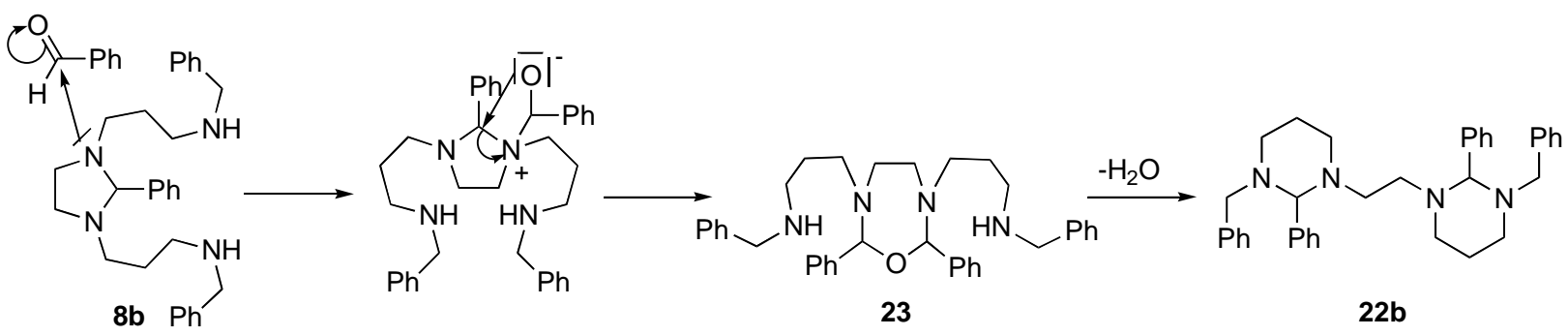

\section{Scheme 8}

All compounds have been fully characterized by NMR spectroscopy, including ${ }^{1} \mathrm{H}-{ }^{1} \mathrm{H}$ and ${ }^{1} \mathrm{H}-{ }^{13} \mathrm{C}$ correlations experiments. It is clear that only one out of the three possible diastereoisomers (EE, $\mathrm{ZZ}$, and $\mathrm{EZ}$ regarding the two $\mathrm{C}=\mathrm{N}$ configurations) is obtained for the monoaminal diimines $\mathbf{7 a}$ and $\mathbf{7 b}$. The EZ isomer is not compatible with the symmetry of the molecule in agreement with the number of signals on the NMR spectra. Single crystals were obtained from recrystallization of $\mathbf{7 a}$ and $\mathbf{7 b}$ in ethanol and THF respectively. In both cases, the most stable EE configuration was undoubtedly confirmed by X-ray diffraction (Figures 1 and 2).

The symmetry observed in solution is not preserved in the solid state, especially in the case of 7b. Indeed, one $\mathrm{C}-\mathrm{N}$ aminal bond is considerably longer than the other one $(1.470 \AA$ vs 1.452 $\AA$ ). The distortion of the five-membered ring can result from interactions between the methylenic protons of the propylene chain and the $\pi$ electrons of the benzyl groups of an adjacent molecule. The loss of symmetry in the solid state is also evidenced by CP-MAS ${ }^{13} \mathrm{C}$ NMR. Indeed, the ${ }^{13} \mathrm{C}$ spectrum of $\mathbf{7 b}$ in the solid state exhibits a splitting or broadening of all signals.

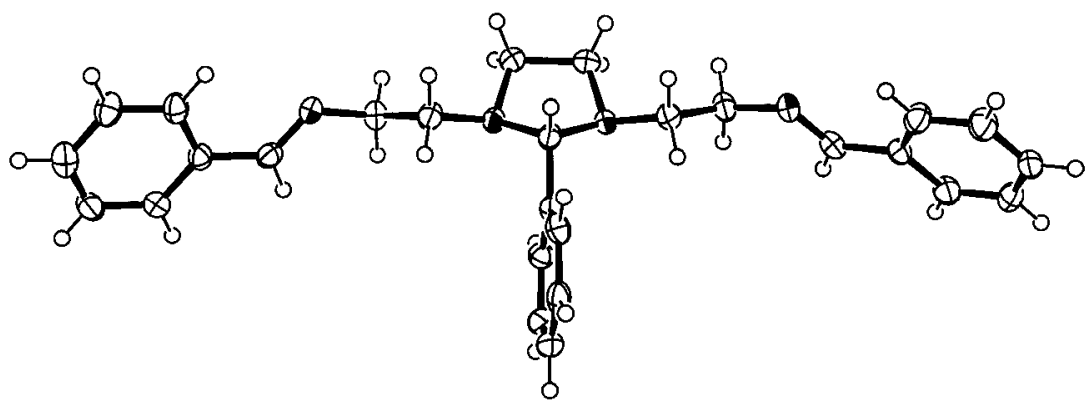

Figure 1. ORTEP view of 7a, showing thermal ellipsoids at $50 \%$ probability level. 


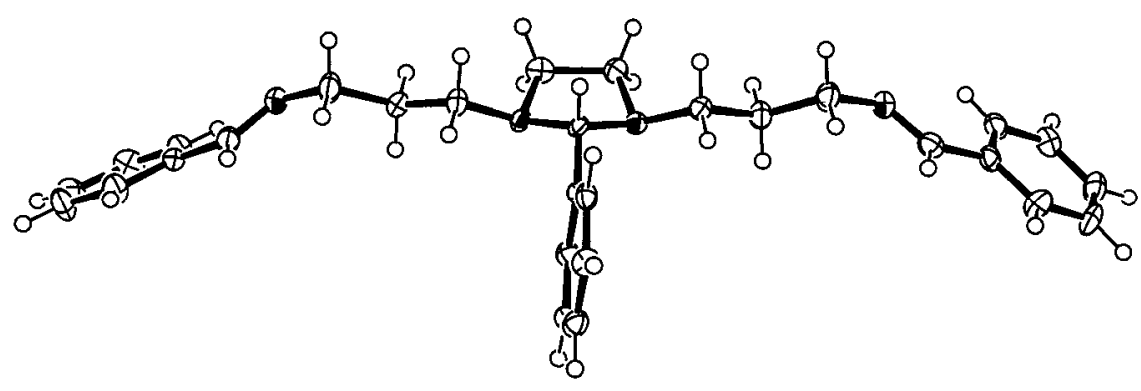

Figure 2. ORTEP view of $\mathbf{7 b}$, showing thermal ellipsoids at $50 \%$ probability level.

The bisaminal compounds 22a and 22b resulting from the rearrangement of $\mathbf{8 a}$ and $\mathbf{8 b}$ can also exist as different stereoisomers, due to the presence of two identical asymmetric carbon atoms, i.e. a meso compound and a racemic mixture of two enantiomers. The ${ }^{13} \mathrm{C}$ NMR of $22 \mathbf{b}$ recorded in $\mathrm{CDCl}_{3}$, exhibits twelve signals in the 20-90 ppm region corresponding to the aliphatic carbon atoms. However, both diastereoisomers are symmetrical and should exhibit only six signals in this region. One may deduce that both compounds are present in this solution. Surprisingly, the spectrum was simplified when recorded in $\mathrm{C}_{6} \mathrm{D}_{6}$. In this solvent, only six signals appear in the region of interest, showing that only one diastereoisomer is present in the solution. The rearrangement gives probably only one compound, which then isomerizes in acidic solvent such as $\mathrm{CDCl}_{3}$, to give a mixture of diastereoisomers. The NMR data given in the experimental section for compounds 22a and $\mathbf{2 2 b}$ are those obtained in $\mathrm{C}_{6} \mathrm{D}_{6}$ as solvent. The structures of bisaminal compounds 22a and 22b have been established unequivocally by single crystal X-ray diffraction (Figures 3 and 4). In both cases, the meso compound is obtained.

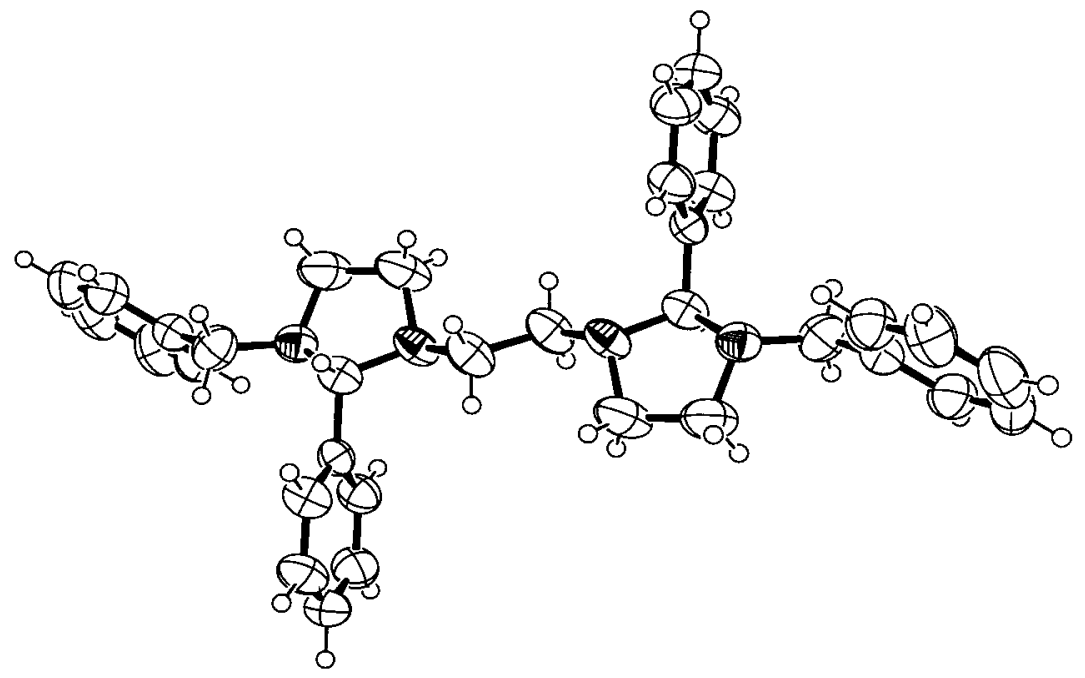

Figure 3. ORTEP view of 22a, showing thermal ellipsoids at $50 \%$ probability level. 


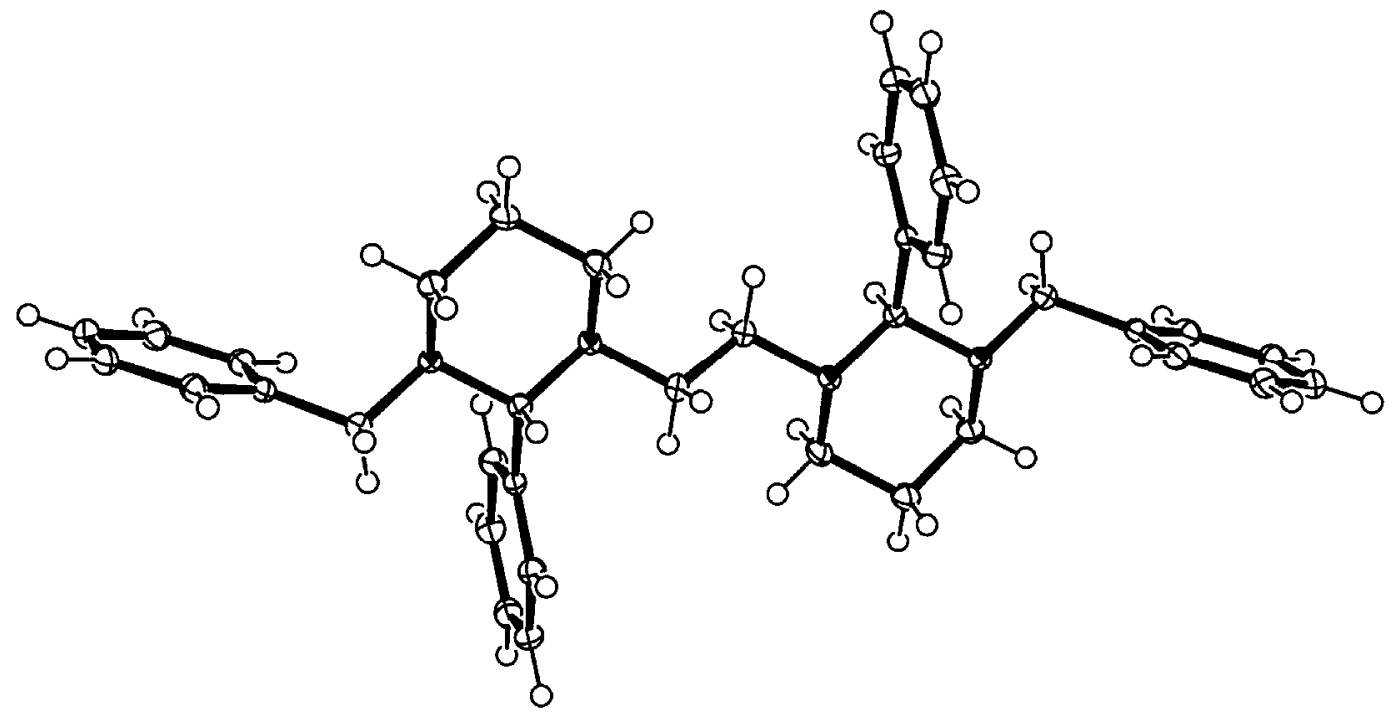

Figure 4. ORTEP view of 22b, showing thermal ellipsoids at $50 \%$ probability level.

\section{Conclusions}

Diethyloxalate proved to be a valuable precursor for the synthesis of polyazacycloalkanes. The cyclization reaction can be performed in good yields without using high dilution conditions, probably due to the conformational rigidity of the diester. However, the nature of the starting polyamine is a key parameter since $[1+1]$ or $[2+2]$ adducts can be preferably obtained depending on the presence or not of benzyl groups on the terminal nitrogen atoms. Indeed, the reaction of ethylene diamine or 1,3-propanediamine with diethyloxalate gives tetraamides which appear to be quite reluctants towards reduction, although cyclam can be obtained in $19 \%$ overall yield, in only two steps, providing that ultrasounds are used during the reduction step. Convenient routes for the synthesis of various di- or tetrabenzylated linear tetraamines have been devised, implying the use of aminal intermediates obtained by reaction of the linear tetraamines with aldehydes. The cyclization of these $N$-benzylated tetraamines with diethyloxalate leads to various 2,3-dioxo $\mathrm{N}$-benzylated tetraazamacrocycles, which after reduction and removal of benzyl groups, can yield cyclen or cyclam. Beside the synthesis of these two tetraazacycloalkanes, the interest of the synthetic routes described herein also lies in the intermediates. Thus, 1,4-dibenzylcyclen and cyclam are valuable cis-diprotected macrocycles for the preparation of new tetraazamacrocyclic ligands. Diamide intermediates also represent a new class of ligands and the coordination properties of these macrocycles incorporating both amine and amide type nitrogen atoms will be studied. Finally, we have shown that the reactivity of five-membered cyclic aminal compounds forbids the use of this moiety as protecting group in the cyclization reaction, but allows the stereoselective synthesis of new bisaminal compounds. 


\section{Experimental Section}

General Procedures. ${ }^{1} \mathrm{H}(200$ or $500 \mathrm{MHz})$ and ${ }^{13} \mathrm{C}$ NMR (50 or $\left.125 \mathrm{MHz}\right)$ spectra were recorded on Bruker AC 200 or Bruker DRX-500 spectrometers at the "Centre de Spectroscopie Moléculaire de l'Université de Bourgogne (CSM FR 2604)". Chemical shifts ( $\delta$ ) were measured by reference to the residual protons or carbon signals of the deuterated solvent. IR spectra were recorded on a Bruker IFS 66v spectrometer. MALDI-TOF mass spectra were recorded on a Bruker Daltonics Proflex III device using dithranol as a matrix. The melting points were determined using a Büchi B-545 apparatus and are uncorrected. Elemental analyses were carried out with a Fisons EA 1108 CHNS instrument at the CSM or done at the "Service Central d'Analyses du CNRS" in Vernaison.

$\mathrm{X}$-Ray data collection and structure refinement. Colourless single-crystals of $7 \mathbf{a}, 7 \mathbf{b}, \mathbf{2 2 a}$ and 22b, were obtained from ethanol, THF, dichloromethane and acetone/dichloromethane (50/50) respectively. For compounds $\mathbf{7 a}, \mathbf{7 b}$ and $\mathbf{2 2} \mathbf{b}$, data collections were carried out at low temperature $(\mathrm{T}=110(2) \mathrm{K})$ on a Nonius KappaCCD diffractometer equipped with a nitrogen jet stream low-temperature system (Oxford Cryosystems), and for compound 22a data were collected at room temperature on a Enraf-Nonius CAD4. In all experiments the X-ray source was graphite monochromatized Mo-K $\alpha$ radiation $(\lambda=0.71073 \AA)$ from a sealed tube. Intensity data were recorded as $\varphi$ and $\omega$ scans with $\kappa$ offsets in the former diffractometer, and as a $\theta / 2 \theta$ scan mode in the later. No significant intensity decay was observed during data collections. No diffractometer or temperature problems occurred during the experiments. A psi-scan absorption correction ${ }^{16}$ was carried out for compound 22a.

In the case of $\mathbf{7 b}$, inspection of the X-ray pattern on the collected images indicated a severe twinning, which did not permit to fit the lattice parameters in an initial stage. Thus, using the data reduction software (DENZO program ${ }^{17}$ ) we omitted a subset of the data, permitting us both to fit good unit-cell parameters and to integrate reflections properly. This procedure led to a completeness of only $52 \%$ up to $\theta_{\max }=25.0^{\circ}$, and therefore to a quite small ratio $\mathrm{N}_{\text {reflections }} /$ $\mathrm{N}_{\text {parameters }}=4.5$. In spite of that, the structure could be solved (the best phase set in the solving procedure gave all the positions for the non-H atoms) and the refinement was very stable and fast converged to the final model.

All the structures were solved by direct methods using the SIR92 program. ${ }^{18}$ While for $7 \mathbf{a}$, $7 \mathbf{b}$ and 22b the refinements were carried out by full-matrix least squares on $\mathrm{F}^{2}$ using the SHELXL97 program $^{19}$ and the complete set of reflections, in the case of 22a the refinement was done by full-matrix least squares on F using the LSFM OpenMolEN program ${ }^{20}$ and the 1220 observed reflections (I $>3 \sigma(\mathrm{I}))$. Anisotropic thermal parameters were refined for non-hydrogen atoms in the four structure determinations. Then, hydrogen atoms were located by Fourier synthesis and placed at calculated positions by using a riding model. They were refined with a global isotropic thermal factor in each structural model. 
Table 1. Crystal and structure refinement data for compounds 7a, 7b, 22a and 22b.

\begin{tabular}{|c|c|c|c|c|}
\hline Compound & $7 \mathbf{a}$ & $7 \mathbf{b}$ & $22 a$ & $22 \mathbf{b}$ \\
\hline Chemical formula & $\mathrm{C}_{27} \mathrm{H}_{30} \mathrm{~N}_{4}$ & $\mathrm{C}_{29} \mathrm{H}_{34} \mathrm{~N}_{4}$ & $\mathrm{C}_{34} \mathrm{H}_{38} \mathrm{~N}_{4}$ & $\mathrm{C}_{36} \mathrm{H}_{42} \mathrm{~N}_{4}$ \\
\hline Formula weight & 410.55 & 438.60 & 502.71 & 530.74 \\
\hline Temperature / K & $110(2)$ & $110(2)$ & $294(2)$ & $110(2)$ \\
\hline Wavelength / Å & 0.71073 & 0.71073 & 0.71073 & 0.71073 \\
\hline Crystal system & Orthorhombic & Orthorhombic & Monoclinic & Monoclinic \\
\hline Space group & $P 2{ }_{1} 2_{1} 2_{1}$ & $P 2{ }_{1}{ }_{1} 2_{1}$ & $C 2 / \mathrm{c}$ & $P 2{ }_{1} / \mathrm{c}$ \\
\hline$a / \AA$ & $5.5430(2)$ & $5.675(1)$ & $21.885(5)$ & $15.1330(2)$ \\
\hline$b / \AA$ & $16.6730(6)$ & $8.873(1)$ & $5.654(1)$ & $5.5580(1)$ \\
\hline$c / \AA$ & $25.2380(12)$ & $49.325(5)$ & $24.591(6)$ & $18.3100(3)$ \\
\hline$\alpha /^{\circ}$ & 90 & 90 & 90 & 90 \\
\hline$\beta /^{\circ}$ & 90 & 90 & $109.47(2)$ & $108.087(1)$ \\
\hline$\gamma 1^{\circ}$ & 90 & 90 & 90 & 90 \\
\hline Volume / $\AA^{3}$ & $2332.46(16)$ & $2483.7(6)$ & $2868.8(12)$ & $1463.94(4)$ \\
\hline$Z, \mathrm{D}_{\text {calc }} / \mathrm{Mg} \mathrm{m}^{-3}$ & $4,1.16$ & $4,1.17$ & $4,1.16$ & $2,1.20$ \\
\hline$\mu / \mathrm{mm}^{-1}$ & 0.070 & 0.070 & 0.069 & 0.071 \\
\hline Crystal size $/ \mathrm{mm}^{3}$ & $0.20 \times 0.18 \times 0.16$ & $0.24 \times 0.22 \times 0.14$ & $0.33 \times 0.28 \times 0.24$ & $0.25 \times 0.20 \times 0.10$ \\
\hline Collected reflections & 5215 & 1634 & 3271 & 8511 \\
\hline Unique reflections & 3075 & 1355 & 3197 & 5523 \\
\hline $\mathrm{R}_{\text {int }}$ & 0.0591 & 0.0206 & 0.0360 & 0.0310 \\
\hline$\theta_{\max } /^{\circ}$ & 27.5 & 25.0 & 27.3 & 33.0 \\
\hline \multirow[t]{3}{*}{ Index ranges } & $0<=\mathrm{h}<=7$ & $0<=\mathrm{h}<=6$ & $-27<=\mathrm{h}<=25$ & $0<=\mathrm{h}<=23$ \\
\hline & $0<=\mathrm{k}<=21$ & $0<=\mathrm{k}<=10$ & $-7<=\mathrm{k}<=0$ & $0<=\mathrm{k}<=8$ \\
\hline & $-32<=1<=32$ & $-53<=1<=58$ & $0<=1<=30$ & $-28<=1<=26$ \\
\hline Data/parameters & $3075 / 282$ & $1355 / 300$ & $1220 / 172$ & $5523 / 182$ \\
\hline$R 1, w R 2^{\mathrm{a}}(\mathrm{I}>2 \sigma(I))$ & $0.0468,0.0901$ & $0.0341,0.0745$ & $0.042,0.054$ & $0.0461,0.1147$ \\
\hline$R 1, w R 2^{\mathrm{a}}$ (all data) & $0.0974,0.1105$ & $0.0406,0.0786$ & $0.133,0.148$ & $0.0587,0.1247$ \\
\hline$\Delta \rho_{\max }, \Delta \rho_{\min } / \mathrm{e} \AA^{-3}$ & $0.189,-0.198$ & $0.121,-0.127$ & $0.134,-0.193$ & $0.394,-0.230$ \\
\hline
\end{tabular}

${ }^{\mathrm{a}} R 1=\Sigma\left\|F_{\mathrm{O}}-F_{\mathrm{C}}\right\| / \Sigma\left|F_{\mathrm{O}}\right|$ and $w R 2=\left[\Sigma\left[w\left(F_{\mathrm{O}}{ }^{2}-F_{\mathrm{C}}{ }^{2}\right)^{2}\right] / \Sigma\left[w\left(F_{\mathrm{O}}{ }^{2}{ }^{2}\right]\right]^{1 / 2}\right.$. 
As far as heavy atoms are not present in the non-centrosymmetric crystal structures of 7a and $\mathbf{7 b}$, their absolute structures were not determined and Friedel pairs were merged in both cases.

For 22b, the first twenty residual peaks observed at the convergence $\left(0.25<\Delta \rho_{\text {res }}<0.39\right.$ $\mathrm{e} \AA^{-3}$ ) correspond to the deformation of the electron distribution in the middle of the covalent bonds and in lone pairs regions.

Table 1 shows crystal data and structure refinement details.

The X-ray diffraction data have been deposited at the Cambridge Crystallographic Data Centre under the registration numbers 295408 (7a), 295409 (7b), 295410 (22a), 295411 (22b).

1,4,8,11-Tetraazacyclotetradecane (2b) via the 1,4,8,11-tetraazacyclotetradecane-2,3,9,10tetraone (1b). A solution of diethyloxalate $(9.85 \mathrm{~g}, 67.4 \mathrm{mmol})$ in THF $(60 \mathrm{~mL})$ was added dropwise to a solution of 1,3-propanediamine $(5.0 \mathrm{~g}, 67.4 \mathrm{mmol})$ in $\mathrm{THF}(70 \mathrm{~mL})$ at $0^{\circ} \mathrm{C}$ and stirred vigorously. The white precipitate formed $(7.2 \mathrm{~g}, 87 \%)$ was filtered and washed with cold THF. Under Ar atmosphere, a 1M BH 3 THF solution $(6.0 \mathrm{~mL}, 6.0 \mathrm{mmol})$ was added dropwise to a suspension of this solid $(1.0 \mathrm{~g}, 3.9 \mathrm{mmol})$ in THF $(50 \mathrm{~mL})$ sonicated with a Sonicator cell disruptor W-375 apparatus $(50 \mathrm{KHz})$. The solution was stirred and sonicated at room temperature for $3 \mathrm{~h}$. After cooling at $0^{\circ} \mathrm{C}$, water $(20 \mathrm{~mL})$ was added. After evaporation of THF, a $6 \mathrm{M} \mathrm{HCl}$ solution $(50 \mathrm{~mL})$ was added and the solution was heated at reflux for $3 \mathrm{~h}$. After cooling at room temperature, $\mathrm{KOH}$ pellets were added $(\mathrm{pH}>11)$, and the solution was extracted 6 times with dichloromethane $(100 \mathrm{~mL})$. The combined organic solutions were dried over anhydrous $\mathrm{MgSO}_{4}$ and evaporated to afford $\mathbf{2 b}$ (cyclam) as a white solid $(0.17 \mathrm{~g}, 22 \%)$. ${ }^{1} \mathrm{H}-\mathrm{NMR}$ (200 $\mathrm{MHz}$, $\left.\mathrm{CDCl}_{3}\right) \delta 1.73(4 \mathrm{H}, \mathrm{q}), 2.47(4 \mathrm{H}, \mathrm{s}), 2.68(8 \mathrm{H}, \mathrm{s}), 2.75(8 \mathrm{H}, \mathrm{t}) ;{ }^{13} \mathrm{C}-\mathrm{NMR}\left(50 \mathrm{MHz}, \mathrm{CDCl}_{3}\right) \delta$ 30.1, 49.9, 50.7; MS m/z: $201\left(\mathrm{M}^{+}+1\right)$; Anal. Calcd. $\mathrm{C}_{10} \mathrm{H}_{24} \mathrm{~N}_{4}$ : C, 59.96; H, 12.08; N, 27.97. Found: C, 59.81; H, 11.91; N 28.12.

1,7-Diphenyl-2,6-diazahepta-1,6-diene (3). A solution of benzaldehyde (14.3 g, $134.9 \mathrm{mmol})$ in ethanol $(15 \mathrm{~mL})$ was added dropwise to a solution of 1,3-propanediamine $(5.0 \mathrm{~g}, 67.4 \mathrm{mmol})$ in refluxing ethanol $(100 \mathrm{~mL})$. The mixture was stirred under reflux for $3 \mathrm{~h}$. The solution was evaporated to afford the crude compound 3 as a pale yellow solid $\left(16.8 \mathrm{~g}, 99 \%\right.$, M.p. $\left.81-83^{\circ} \mathrm{C}\right)$; ${ }^{1} \mathrm{H}-\mathrm{NMR}\left(200 \mathrm{MHz}, \mathrm{CDCl}_{3}\right) \delta 2.14(2 \mathrm{H}, \mathrm{q}), 3.73(4 \mathrm{H}, \mathrm{t}), 7.38(10 \mathrm{H}, \mathrm{m}), 7.73(2 \mathrm{H}, \mathrm{s}) ;{ }^{13} \mathrm{C}-\mathrm{NMR}$ $\left(50 \mathrm{MHz}, \mathrm{CDCl}_{3}\right) \delta 32.1,59.3,128.2,128.7,130.7,136.4,161.4 ; \mathrm{IR}\left(\mathrm{KBr}, v_{\mathrm{C}=\mathrm{N}} \mathrm{cm}^{-1}\right) 1650 ; \mathrm{MS}$ m/z: $251\left(\mathrm{M}^{+}+1\right)$; Anal. Calcd. $\mathrm{C}_{17} \mathrm{H}_{18} \mathrm{~N}_{2}$ : C, 81.56; H, 7.25; N, 11.19. Found: C, 82.10; H, 7.04; $\mathrm{N}, 11.66$.

$N, N$ '-Dibenzyl-1,3-propanediamine (4). An excesss of sodium borohydride (6.0 g, 159.6 mmol) was added to a solution of $3(10.0 \mathrm{~g}, 39.9 \mathrm{mmol})$ in ethanol $(150 \mathrm{~mL})$. The mixture was stirred at room temperature for $2 \mathrm{~h}$, cooled to $0^{\circ} \mathrm{C}$ and $15 \mathrm{~mL}$ of water were added. The solution was evaporated and the residue was dissolved in the minimum amount of water. The aqueous phase was extracted 6 times with dichloromethane $(100 \mathrm{~mL})$. The combined organic solutions were dried over anhydrous $\mathrm{MgSO}_{4}$ and evaporated to give 4 as a colorless oil $(8.1 \mathrm{~g}, 80 \%)$. ${ }^{1} \mathrm{H}$ NMR (200 MHz, $\left.\mathrm{CDCl}_{3}\right) \delta 1.73(2 \mathrm{H}, \mathrm{q}), 2.01(2 \mathrm{H}, \mathrm{s}), 2.70(4 \mathrm{H}, \mathrm{t}), 3.78(4 \mathrm{H}, \mathrm{s}), 7.29(10 \mathrm{H}, \mathrm{m})$; 
${ }^{13} \mathrm{C}-\mathrm{NMR}\left(50 \mathrm{MHz}, \mathrm{CDCl}_{3}\right) \delta 30.3,48.1,54.2,126.0,128.2,128.7,140.6 ; \mathrm{MS} \mathrm{m} / \mathrm{z}: 254\left(\mathrm{M}^{+}\right)$; Anal. Calcd. $\mathrm{C}_{17} \mathrm{H}_{22} \mathrm{~N}_{2}$ : C, 80.27; H, 8.72; N, 11.01. Found: C, 80.69; H, 8.04; N, 11.46.

$\boldsymbol{N}, \boldsymbol{N}$ '-Dibenzyl-1,4-diazacycloheptane-2,3-dione (5). A solution of diethyloxalate (11.5 g, 7.9 $\mathrm{mmol})$ in ethanol $(30 \mathrm{~mL})$ was added dropwise to a solution of 4 (2.0 g, $7.9 \mathrm{mmol})$ in ethanol (50 $\mathrm{mL}$ ) at room temperature. The solution was stirred at room temperature for $12 \mathrm{~h}$ and then evaporated. The white solid obtained was washed with cold ethanol and recrystallized from ethanol to give 5 as white spangles $\left(2.0 \mathrm{~g}, 83 \%\right.$, M.p. $\left.=156^{\circ} \mathrm{C}\right) .{ }^{1} \mathrm{H}-\mathrm{NMR}\left(200 \mathrm{MHz}, \mathrm{CDCl}_{3}\right) \delta$ $1.27(2 \mathrm{H}, \mathrm{q}), 3.27(4 \mathrm{H}, \mathrm{t}), 4.59(4 \mathrm{H}, \mathrm{s}), 7.28(10 \mathrm{H}, \mathrm{m}) ;{ }^{13} \mathrm{C}-\mathrm{NMR}\left(50 \mathrm{MHz}, \mathrm{CDCl}_{3}\right) \delta 27.9,43.8$, 50.0, 127.8, 128.4, 130.1, 137.1, 164.9; IR (KBr, $\left.v_{\mathrm{C}=\mathrm{O}} \mathrm{cm}^{-1}\right)$ 1670; MS m/z: $309\left(\mathrm{M}^{+}+1\right)$; Anal. Calcd. $\mathrm{C}_{19} \mathrm{H}_{20} \mathrm{~N}_{2} \mathrm{O}_{2}$ : C, 74.00; H, 6.54; N, 9.08. Found: C, 74.09; H, 6.79; N, 9.32.

$\boldsymbol{N}, \boldsymbol{N}$ '-Dibenzyl-1,4-diazacycloheptane (6). Under Ar atmosphere, a $1 \mathrm{M} \mathrm{BH}_{3} / \mathrm{THF}$ solution (13 $\mathrm{mL}, 13 \mathrm{mmol})$ was added dropwise to a solution of $5(1.0 \mathrm{~g}, 3.25 \mathrm{mmol})$ in anhydrous THF (40 $\mathrm{mL})$. The solution was heated at reflux for $1 \mathrm{~h}$. After cooling at $0^{\circ} \mathrm{C}$, water $(20 \mathrm{~mL})$ was added. THF was evaporated, a $6 \mathrm{M} \mathrm{HCl}$ solution $(50 \mathrm{~mL})$ was added and the solution was heated at reflux for $3 \mathrm{~h}$. After cooling at room temperature, $\mathrm{KOH}$ pellets were added $(\mathrm{pH}>11)$, and the solution was extracted 6 times with dichloromethane $(100 \mathrm{~mL})$. The combined organic solutions were dried over anhydrous $\mathrm{MgSO}_{4}$ and evaporated to afford 6 as a colorless oil (0.88 g, 97\%). ${ }^{1} \mathrm{H}-\mathrm{NMR}\left(200 \mathrm{MHz}, \mathrm{CDCl}_{3}\right) \delta 1.77(2 \mathrm{H}, \mathrm{q}), 2.68(4 \mathrm{H}, \mathrm{s}), 2.77(4 \mathrm{H}, \mathrm{t}), 3.65(4 \mathrm{H}, \mathrm{s}), 7.28(10 \mathrm{H}$, $\mathrm{m}) ;{ }^{13} \mathrm{C}-\mathrm{NMR}\left(50 \mathrm{MHz}, \mathrm{CDCl}_{3}\right) \delta 28.2,55.0,55.6,63.3,127.4,128.7,129.4,140.3 ; \mathrm{MS} \mathrm{m} / \mathrm{z}$ : $280\left(\mathrm{M}^{+}\right)$; Anal. Calcd. $\mathrm{C}_{19} \mathrm{H}_{24} \mathrm{~N}_{2}$ : C, 81.38; H, 8.63; N, 10.00. Found: C, 81.89; H, 8.28; N, 9.82. 2-Phenyl-1,3-bis[(3'-aza-4'-phenyl)-but-3'-enyl]-1,3-imidazolidine (7a). A solution of benzaldehyde $(21.8 \mathrm{~g}, 205 \mathrm{mmol})$ in anhydrous ethanol $(35 \mathrm{~mL})$ was added dropwise to a solution of $N, N^{\prime}$-triethylenetetraamine $(10.0 \mathrm{~g}, 68 \mathrm{mmol})$ in refluxing anhydrous ethanol (110 $\mathrm{mL}$ ). The mixture was stirred under reflux for $12 \mathrm{~h}$. The solution was evaporated to afford a yellow oil. Cold ethanol $(10 \mathrm{~mL})$ was added to the crude product and the white precipitate was filtered and washed with cold acetone to give $7 \mathbf{a}$ as a white solid $\left(26.5 \mathrm{~g}, 94 \%\right.$, M.p. $\left.=87-88^{\circ} \mathrm{C}\right)$ which can be recrystallized in THF or used without further purification in the following steps. ${ }^{1} \mathrm{H}-\mathrm{NMR}\left(200 \mathrm{MHz}, \mathrm{CDCl}_{3}\right) \delta$ 2.5-2.8 (6H, m), 2.5-3.7 (7H, m), 7.2-7.5 (15H, m), $7.7(2 \mathrm{H}, \mathrm{s})$; ${ }^{13} \mathrm{C}-\mathrm{NMR}\left(50 \mathrm{MHz}, \mathrm{CDCl}_{3}\right) \delta 51.7,53.2,60.4,89.4,127.9,128.3,128.4,129.3,129.5,130.4$, 136.0, 140.0, 161.7; IR (KBr, $\left.v_{\mathrm{C}=\mathrm{N}} \mathrm{cm}^{-1}\right)$ 1650; MS m/z: $410\left(\mathrm{M}^{+}\right)$; Anal. Calcd. $\mathrm{C}_{27} \mathrm{H}_{30} \mathrm{~N}_{4}$ : C, 78.99; H, 7.37; N, 13.65. Found: C, 79.52; H, 7.23; N, 14.01.

2-Phenyl-1,3-bis[(4'-aza-5'-phenyl)-pent-4'-enyl]-1,3-imidazolidine (7b). According to the procedure used for the synthesis of 7a, a solution of benzaldehyde (18.2 g, $171 \mathrm{mmol})$ in anhydrous ethanol $(30 \mathrm{~mL})$ and a solution of $N, N^{\prime}$-bis-(3-aminopropyl)-ethylenediamine (10.0 g, $57 \mathrm{mmol})$ in anhydrous ethanol $(100 \mathrm{~mL})$ were reacted to afford $7 \mathbf{b}$ as a white solid $(24.1 \mathrm{~g}$, $96 \%$, M.p. $=100-101{ }^{\circ} \mathrm{C}$ ) which can be recrystallized in abs. ethanol or used without further purification in the following steps. ${ }^{1} \mathrm{H}-\mathrm{NMR}\left(500 \mathrm{MHz}, \mathrm{CDCl}_{3}\right) \delta 1.76(4 \mathrm{H}, \mathrm{m}), 2.22(2 \mathrm{H}, \mathrm{m})$, $2.45(2 \mathrm{H}, \mathrm{m}), 2.55(2 \mathrm{H}, \mathrm{m}), 3.35(2 \mathrm{H}, \mathrm{m}), 3.45(2 \mathrm{H}, \mathrm{m}), 3.75(2 \mathrm{H}, \mathrm{m}), 3.80(1 \mathrm{H}, \mathrm{s}), 7.25-7.68$ $(15 \mathrm{H}, \mathrm{m}), 8.02(2 \mathrm{H}, \mathrm{s}) ;{ }^{13} \mathrm{C}-\mathrm{NMR}\left(125 \mathrm{MHz}, \mathrm{CDCl}_{3}\right) \delta 29.5,50.4,50.9,59.2,90.0,125.2,126.6$, 
127.4, 128.3, 129.4, 130.5, 136.3, 140.8, 161.3; IR (KBr, $\left.v_{\mathrm{C}=\mathrm{N}} \mathrm{cm}^{-1}\right) 1650 ; \mathrm{MS} \mathrm{m} / \mathrm{z}: 438\left(\mathrm{M}^{+}\right)$; Anal. Calcd. $\mathrm{C}_{29} \mathrm{H}_{34} \mathrm{~N}_{4}$ : C, 79.41; H, 7.81; N, 12.77. Found: C, 79.35; H, 7.83; N, 12.52 .

2-(2-Pyridyl)-1,3-bis[4'-aza-5'-(2-pyridyl)-pent-4'-enyl]-1,3-imidazolidine (13a). According to the procedure used for the synthesis of 7a, a solution of 2-pyridinecarboxaldehyde (18.4 $\mathrm{g}$, $172 \mathrm{mmol})$ in anhydrous ethanol $(30 \mathrm{~mL})$ and a solution of $N, N$ '-bis-(3-aminopropyl)ethylenediamine $(10.0 \mathrm{~g}, 57 \mathrm{mmol})$ in anhydrous ethanol $(100 \mathrm{~mL})$ were reacted to afford 13a as a pale yellow solid (25.1 g, 99\%). ${ }^{1} \mathrm{H}-\mathrm{NMR}\left(200 \mathrm{MHz}, \mathrm{CDCl}_{3}\right) \delta 1.63(4 \mathrm{H}, \mathrm{q}), 2.01-2.52(6 \mathrm{H}$, m), 3.22-3.78 (7H, m), 6.75-8.43 (14H, m); ${ }^{13} \mathrm{C}-\mathrm{NMR}\left(50 \mathrm{MHz}, \mathrm{CDCl}_{3}\right) \delta$ 29.4, 50.7, 51.1, 58.9, $90.4,121.2,122.9,124.6,136.5,136.7,147.9,148.2,149.3,154.4,161.6,161.9$; IR $\left(\mathrm{KBr}, v_{\mathrm{C}=\mathrm{N}}\right.$ $\left.\mathrm{cm}^{-1}\right)$ 1650; MS m/z: $442\left(\mathrm{M}^{+}+1\right)$; Anal. Calcd. $\mathrm{C}_{26} \mathrm{H}_{31} \mathrm{~N}_{7}: \mathrm{C}, 70.72 ; \mathrm{H}, 7.08 ; \mathrm{N}, 22.20$. Found: C, 70.32; H, 7.53; N, 23.01 .

\section{2-(3-Bromophenyl)-1,3-bis[4'-aza-5'-(3-bromophenyl)-pent-4'-enyl]-1,3-imidazolidine}

(13b). According to the procedure used for the synthesis of 7a, a solution of 3bromobenzaldehyde $(31.8 \mathrm{~g}, 172 \mathrm{mmol})$ in anhydrous ethanol $(30 \mathrm{~mL})$ and a solution of $N, N$ 'bis-(3-aminopropyl)-ethylenediamine $(10.0 \mathrm{~g}, 57 \mathrm{mmol})$ in anhydrous ethanol $(100 \mathrm{~mL})$ were reacted to afford $\mathbf{1 3 b}$ as a pale yellow oil $(38.2 \mathrm{~g}, 99 \%)$. ${ }^{1} \mathrm{H}-\mathrm{NMR}\left(200 \mathrm{MHz}, \mathrm{CDCl}_{3}\right) \delta 1.73(4 \mathrm{H}$, q), 2.15-2.66 (8H, m), 3.25-3.42 $(5 \mathrm{H}, \mathrm{m}), 6.91-7.92(14 \mathrm{H}, \mathrm{m}) ;{ }^{13} \mathrm{C}-\mathrm{NMR}\left(50 \mathrm{MHz}, \mathrm{CDCl}_{3}\right) \delta$ 29.1, 50.1, 50.9, 58.6, 89.3, 122.3, 122.8, 126.8, 128.1, 129.6, 130.1, 130.7, 131.5, 132.1, 133.3, 138.2, 143.8, 159.6; IR (KBr, $\left.v_{\mathrm{C}=\mathrm{N}} \mathrm{cm}^{-1}\right)$ 1650; MS m/z: $673\left(\mathrm{M}^{+}+1\right)$; Anal. Calcd. $\mathrm{C}_{29} \mathrm{H}_{31} \mathrm{~N}_{4} \mathrm{Br}_{3}$ : C, 51.58; H, 4.63; N, 8.30. Found: C, 52.21; H, 4.83; N, 8.61.

2-Phenyl-1,3-bis[4'-aza-5'-(phenyl)-pentyl]-1,3-imidazolidine (8b). According to the procedure used for the synthesis of $\mathbf{4}$, sodium borohydride $(3.5 \mathrm{~g}, 91.2 \mathrm{mmol})$ and a solution of 7b $(10.0 \mathrm{~g}, 23 \mathrm{mmol})$ in ethanol $(100 \mathrm{~mL})$ were reacted to afford $\mathbf{8 b}$ as a colorless oil $(9.9 \mathrm{~g}$, 98\%). ${ }^{1} \mathrm{H}-\mathrm{NMR}\left(200 \mathrm{MHz}, \mathrm{CDCl}_{3}\right) \delta 1.38(2 \mathrm{H}, \mathrm{s}), 1.57(4 \mathrm{H}, \mathrm{m}), 2.10-2.64(12 \mathrm{H}, \mathrm{m}), 3.41(1 \mathrm{H}$, s), $3.64(4 \mathrm{H}, \mathrm{s}), 7.24(15 \mathrm{H}, \mathrm{m}) ;{ }^{13} \mathrm{C}-\mathrm{NMR}\left(50 \mathrm{MHz}, \mathrm{CDCl}_{3}\right) \delta 28.5,47.7 .50 .9,50.9,54.1,90.2$, 125.4, 125.9, 126.8, 128.1, 129.5, 131.5, 134.9, 140.5; MS m/z: $443\left(\mathrm{M}^{+}+1\right)$; Anal. Calcd. $\mathrm{C}_{29} \mathrm{H}_{38} \mathrm{~N}_{4}$ : C, 78.69; H, 8.65; N, 12.66. Found: C, 79.01; H, 8.99; N, 12.95.

2-(2-Pyridyl)-1,3-bis[4'-aza-5'-(2-pyridyl)-pentyl]-1,3-imidazolidine (14a). According to the procedure used for the synthesis of 4 , sodium borohydride $(3.42 \mathrm{~g}, 90.4 \mathrm{mmol})$ and a solution of 13a $(10.0 \mathrm{~g}, 22.6 \mathrm{mmol})$ in ethanol $(100 \mathrm{~mL})$ were reacted to afford 14a as a pale yellow oil $(9.0$ g, 89\%). ${ }^{1} \mathrm{H}-\mathrm{NMR}\left(200 \mathrm{MHz}, \mathrm{CDCl}_{3}\right) \delta 1.47(4 \mathrm{H}, \mathrm{q}), 1.72(2 \mathrm{H}, \mathrm{s}), 2.01-2.75(10 \mathrm{H}, \mathrm{m}), 3.11-3.39$ $(2 \mathrm{H}, \mathrm{m}), 3.55-3.83(5 \mathrm{H}, \mathrm{m}), 6.82-8.42(12 \mathrm{H}, \mathrm{m}) ;{ }^{13} \mathrm{C}-\mathrm{NMR}\left(50 \mathrm{MHz}, \mathrm{CDCl}_{3}\right) \delta 28.8,47.8,51.1$, 51.3, 55.4, 90.5, 122.5, 122.7, 122.9, 123.1, 136.5, 136.7, 148.1, 149.2, 159.9, 162.5; MS m/z: $446\left(\mathrm{M}^{+}+1\right)$; Anal. Calcd. $\mathrm{C}_{26} \mathrm{H}_{35} \mathrm{~N}_{7}$ : C, 70.08; H, 7.92; N, 22.00. Found: C, 70.62; H, 7.43; N, 21.81 .

\section{2-(3-Bromophenyl)-1,3-bis[4'-aza-5'-(3-bromophenyl)-pentyl]-1,3-imidazolidine}

(14b).

According to the procedure used for the synthesis of 4, sodium borohydride $(2.25 \mathrm{~g}, 59.6 \mathrm{mmol})$ and a solution of $\mathbf{1 3 b}(10.0 \mathrm{~g}, 14.9 \mathrm{mmol})$ in ethanol $(100 \mathrm{~mL})$ were reacted to afford $\mathbf{1 4 b}$ as a pale yellow oil (8.2 g, 82\%). ${ }^{1} \mathrm{H}-\mathrm{NMR}\left(200 \mathrm{MHz}, \mathrm{CDCl}_{3}\right) \delta 1.52(4 \mathrm{H}, \mathrm{q}), 1.89(2 \mathrm{H}, \mathrm{s}), 2.12-2.71$ $(12 \mathrm{H}, \mathrm{m}), 3.39(1 \mathrm{H}, \mathrm{s}), 3.58(4 \mathrm{H}, \mathrm{s}), 7.0-7.5(12 \mathrm{H}, \mathrm{m}) ;{ }^{13} \mathrm{C}-\mathrm{NMR}\left(50 \mathrm{MHz}, \mathrm{CDCl}_{3}\right) \delta 28.4,47.5$, 
$50.8,50.9,53.5,89.3,122.4,122.5,126.6,126.7,127.9,129.9,130.0,131.1,131.7,132.0,143.1$, 143.8; MS m/z: $677\left(\mathrm{M}^{+}+1\right)$; Anal. Calcd. $\mathrm{C}_{29} \mathrm{H}_{35} \mathrm{~N}_{4} \mathrm{Br}_{3}$ : C, 51.27; H, 5.19; N, 8.25. Found: $\mathrm{C}$, $52.01 ; \mathrm{H}, 5.88 ; \mathrm{N}, 8.51$.

1,10-Dibenzyl-1,4,7,10-tetraazadecane (9a). An excesss of sodium borohydride (3.5 g, 91.2 mmol) was added to a solution of $7 \mathbf{a}(10.0 \mathrm{~g}, 24 \mathrm{mmol})$ in ethanol $(100 \mathrm{~mL})$. The mixture was stirred at room temperature for $2 \mathrm{~h}$, cooled to $0^{\circ} \mathrm{C}$ and a $6 \mathrm{M} \mathrm{HBr}$ solution $(30 \mathrm{~mL})$ was added. The white solid formed was filtered, washed with cold ethanol and dissolved in the minimum amount of water. $\mathrm{KOH}$ pellets were added $(\mathrm{pH}>11)$ and the solution was extracted 6 times with dichloromethane $(100 \mathrm{~mL})$. The combined organic solutions were dried over anhydrous $\mathrm{MgSO}_{4}$ and evaporated to afford 9a as a pale yellow oil $(4.55 \mathrm{~g}, 58 \%)$. ${ }^{1} \mathrm{H}-\mathrm{NMR}\left(200 \mathrm{MHz}, \mathrm{CDCl}_{3}\right) \delta$ $1.60(4 \mathrm{H}, \mathrm{s}), 2.55(4 \mathrm{H}, \mathrm{s}), 2.59(8 \mathrm{H}, \mathrm{m}), 3.63(4 \mathrm{H}, \mathrm{s}), 7.10(10 \mathrm{H}, \mathrm{m}) ;{ }^{13} \mathrm{C}-\mathrm{NMR}(50 \mathrm{MHz}$, $\left.\mathrm{CDCl}_{3}\right) \delta$ 48.8, 49.3, 49.3, 53.9, 126.9, 128.1, 128.4, 140.5; MS m/z: $326\left(\mathrm{M}^{+}\right)$; Anal. Calcd. $\mathrm{C}_{20} \mathrm{H}_{30} \mathrm{~N}_{4}$ : C, 73.58; H, 9.26; N, 17.16. Found: C, 74.21; H, 9.82; N, 16.67 .

1,12-Dibenzyl-1,5,8,12-tetraazadodecane (9b). A $6 \mathrm{M} \mathrm{HBr}$ solution $(30 \mathrm{~mL})$ was added to a solution of $\mathbf{8 b}(9.9 \mathrm{~g}, 22.3 \mathrm{mmol})$ in ethanol $(100 \mathrm{~mL})$. The white solid formed was filtered, washed with cold ethanol and dissolved in the minimum amount of water. $\mathrm{KOH}$ pellets were added $(\mathrm{pH}>11)$ and the solution was extracted 6 times with dichloromethane $(100 \mathrm{~mL})$. The combined organic solutions were dried over anhydrous $\mathrm{MgSO}_{4}$ and evaporated to afford $\mathbf{9 b}$ as a colorless oil (7.6 g, 96\%). ${ }^{1} \mathrm{H}-\mathrm{NMR}\left(200 \mathrm{MHz}, \mathrm{CDCl}_{3}\right) \delta 1.28(4 \mathrm{H}, \mathrm{s}), 1.60(4 \mathrm{H}, \mathrm{q}), 2.57(4 \mathrm{H}, \mathrm{t})$, $2.61(4 \mathrm{H}, \mathrm{t}), 2.64(4 \mathrm{H}, \mathrm{s}), 3.69(4 \mathrm{H}, \mathrm{s}), 7.22(10 \mathrm{H}, \mathrm{m}) ;{ }^{13} \mathrm{C}-\mathrm{NMR}\left(50 \mathrm{MHz}, \mathrm{CDCl}_{3}\right) \delta 30.4,47.9$, 48.5, 49.6, 54.1, 126.8, 128.1, 128.4, 140.6; MS m/z: $354\left(\mathrm{M}^{+}\right)$; Anal. Calcd. $\mathrm{C}_{22} \mathrm{H}_{34} \mathrm{~N}_{4}$ : C, 74.53; H, 9.67; N, 15.80. Found: C, 74.08; H, 9.82; N, 16.02 .

1,14-Bis(2-pyridyl)-2,6,9,13-tetraazatetradecane (15a). According to the procedure used for the synthesis of $9 \mathbf{b}$, a $6 \mathrm{M} \mathrm{HBr}$ solution $(15 \mathrm{~mL})$ and a solution of $14 \mathbf{a}(5.0 \mathrm{~g}, 11.2 \mathrm{mmol})$ in ethanol $(50 \mathrm{~mL})$ were reacted to afford a mixture (1/1 ratio) of 15a and 1,14-bis(2-pyridyl)-6-(2pyridylmethyl)-2,6,9,13-tetraazatetradecane (16a) which were separated by chromatography on alumina $\left[\mathrm{CH}_{2} \mathrm{Cl}_{2}\right.$ then $\mathrm{CH}_{2} \mathrm{Cl}_{2}-\mathrm{MeOH}$ (100:5)]. The compound 15a was obtained as the sole product when the reaction was performed in refluxing water $(3.6 \mathrm{~g}, 89 \%) .{ }^{1} \mathrm{H}-\mathrm{NMR}(200 \mathrm{MHz}$, $\left.\mathrm{CDCl}_{3}\right) \delta 1.59(4 \mathrm{H}, \mathrm{q}), 2.26(4 \mathrm{H}, \mathrm{s}), 2.53(4 \mathrm{H}, \mathrm{t}), 2.56(4 \mathrm{H}, \mathrm{s}), 2.62(4 \mathrm{H}, \mathrm{t}), 3.78(4 \mathrm{H}, \mathrm{s}), 6.8-8.5$ $(8 \mathrm{H}, \mathrm{m}) ;{ }^{13} \mathrm{C}-\mathrm{NMR}\left(50 \mathrm{MHz}, \mathrm{CDCl}_{3}\right) \delta 30.3,47.9,48.2,49.4,55.2,121.9,122.3,136.5,149.2$; 159.7; MS m/z: $356\left(\mathrm{M}^{+}\right)$; Anal. Calcd. $\mathrm{C}_{20} \mathrm{H}_{32} \mathrm{~N}_{6}$ : C, 67.38; H, 9.05; N, 23.57. Found: $\mathrm{C}, 68.21$; $\mathrm{H}, 9.53 ; \mathrm{N}, 22.91$.

1,14-Bis(3-bromophenyl)-2,6,9,13-tetraazatetradecane (15b). According to the procedure used for the synthesis of $\mathbf{9 b}$, a $6 \mathrm{M} \mathrm{HBr}$ solution $(15 \mathrm{~mL})$ and a solution of $\mathbf{1 4 b}(5.0 \mathrm{~g}, 7.4 \mathrm{mmol})$ in ethanol $(50 \mathrm{~mL})$ were reacted to afford 15b as a pale yellow oil $(3.0 \mathrm{~g}, 80 \%)$. ${ }^{1} \mathrm{H}-\mathrm{NMR}(200$ $\left.\mathrm{MHz}, \mathrm{CDCl}_{3}\right) \delta 1.40(4 \mathrm{H}, \mathrm{s}), 1.61(4 \mathrm{H}, \mathrm{q}), 2.56(4 \mathrm{H}, \mathrm{t}), 2.57(4 \mathrm{H}, \mathrm{t}), 2.63(4 \mathrm{H}, \mathrm{s}), 3.68(4 \mathrm{H}, \mathrm{s})$, 7.1-7.5 (8H, m); ${ }^{13} \mathrm{C}-\mathrm{NMR}\left(50 \mathrm{MHz}, \mathrm{CDCl}_{3}\right) \delta 30.3,47.9,48.5,49.6,53.5,122.6,126.7,129.9$, 130.0, 131.1, 143.1; MS m/z: $610\left(\mathrm{M}^{+}\right)$; Anal. Calcd. $\mathrm{C}_{22} \mathrm{H}_{32} \mathrm{~N}_{4} \mathrm{Br}_{2}$ : C, 51.58; H, 6.30; N, 10.94 . Found: C, 52.20; H, 6.53; N, 11.32 . 
5,8-Dibenzyl-1,12-diphenyl-2,5,8,11-tetraazatetradodecane-1,11-diene (10a). Benzyl bromide $(8.34 \mathrm{~g}, 48.7 \mathrm{mmol})$ was added dropwise to a solution of $7 \mathbf{a}(10.0 \mathrm{~g}, 24.3 \mathrm{mmol})$ and $\mathrm{K}_{2} \mathrm{CO}_{3}(20$ $\mathrm{g}, 145 \mathrm{mmol})$ in refluxing acetonitrile $(200 \mathrm{~mL})$. The mixture was stirred under reflux for $12 \mathrm{~h}$. The solid was filtered off and the solution was evaporated to afford a yellow oil which was chromatographed on alumina $\left[\mathrm{CH}_{2} \mathrm{Cl}_{2}\right.$ then $\left.\mathrm{CH}_{2} \mathrm{Cl}_{2}-\mathrm{MeOH}(100: 5)\right]$ to give 10a as a colorless oil (8.71 g, 71\%). ${ }^{1} \mathrm{H}-\mathrm{NMR}\left(200 \mathrm{MHz}, \mathrm{CDCl}_{3}\right) \delta 2.71(4 \mathrm{H}, \mathrm{s}), 2.81(4 \mathrm{H}, \mathrm{t}), 3.52(4 \mathrm{H}, \mathrm{t}), 3.66(4 \mathrm{H}$, s), 7.2-8.2 (20H, m), $8.31(2 \mathrm{H}, \mathrm{s}) ;{ }^{13} \mathrm{C}-\mathrm{NMR}\left(50 \mathrm{MHz}, \mathrm{CDCl}_{3}\right) \delta$ 52.7, 55.1, 59.6, 60.0, 126.9, 128.2, 128.7, 128.9, 129.1, 129.9, 136.4, 139.9, 161.9; IR (neat, $v_{\mathrm{C}=\mathrm{N}} \mathrm{cm}^{-1}$ ) 1650; MS m/z: 503 $\left(\mathrm{M}^{+}+1\right)$; Anal. Calcd. $\mathrm{C}_{34} \mathrm{H}_{38} \mathrm{~N}_{4}$ : C, 81.24; H, 7.62; N, 11.15. Found: C, 79.92; H, 7.17; N, 10.89.

6,9-Dibenzyl-1,14-diphenyl-2,6,9,13-tetraazatetradecane-1,13-diene (10b). According to the procedure used for the synthesis of 10a, benzyl bromide $(11.7 \mathrm{~g}, 68 \mathrm{mmol})$ and a solution of $7 \mathbf{b}$ (15.0 g, $34 \mathrm{mmol}) \mathrm{K}_{2} \mathrm{CO}_{3}(30 \mathrm{~g}, 220 \mathrm{mmol})$ in acetonitrile $(300 \mathrm{~mL})$ were reacted to afford $\mathbf{1 0 b}$ as a colorless oil $(15.9 \mathrm{~g}, 88 \%) .{ }^{1} \mathrm{H}-\mathrm{NMR}\left(200 \mathrm{MHz}, \mathrm{CDCl}_{3}\right) \delta 1.83(4 \mathrm{H}, \mathrm{q}), 2.49(4 \mathrm{H}, \mathrm{t}), 2.58$ $(4 \mathrm{H}, \mathrm{s}), 3.56(4 \mathrm{H}, \mathrm{s}), 3.57(4 \mathrm{H}, \mathrm{t}), 7.1-7.9(20 \mathrm{H}, \mathrm{m}), 8.02(2 \mathrm{H}, \mathrm{s}) ;{ }^{13} \mathrm{C}-\mathrm{NMR}\left(50 \mathrm{MHz}, \mathrm{CDCl}_{3}\right) \delta$ 28.4, 52.0, 52.1, 59.0, 59.6, 126.8, 128.1, 128.2, 128.6, 128.9, 130.5, 136.4, 139.9, 161.1; IR (neat, $v_{\mathrm{C}=\mathrm{N}} \mathrm{cm}^{-1}$ ) 1650; MS m/z: $530\left(\mathrm{M}^{+}\right)$; Anal. Calcd. $\mathrm{C}_{36} \mathrm{H}_{42} \mathrm{~N}_{4}: \mathrm{C}, 81.47 ; \mathrm{H}, 7.98 ; \mathrm{N}, 10.56$. Found: C, 81.01; H, 8.31; N, 11.20.

4,7-Dibenzyl-1,4,7,10-tetraazadecane (11a). According to the procedure used for the synthesis of $9 \mathbf{b}$, a $6 \mathrm{M} \mathrm{HBr}$ solution $(15 \mathrm{~mL})$ and a solution of $10 \mathrm{a}(5.0 \mathrm{~g}, 10 \mathrm{mmol})$ in ethanol $(50 \mathrm{~mL})$ were reacted to afford 11a as a pale yellow oil $(2.31 \mathrm{~g}, 71 \%)$. ${ }^{1} \mathrm{H}-\mathrm{NMR}\left(200 \mathrm{MHz}, \mathrm{CDCl}_{3}\right) \delta$ $1.49(4 \mathrm{H}, \mathrm{s}), 2.43(4 \mathrm{H}, \mathrm{t}), 2.54(4 \mathrm{H}, \mathrm{s}), 2.64(4 \mathrm{H}, \mathrm{t}), 3.49(4 \mathrm{H}, \mathrm{s}), 7.22(10 \mathrm{H}, \mathrm{m}) ;{ }^{13} \mathrm{C}-\mathrm{NMR}(50$ $\left.\mathrm{MHz}, \mathrm{CDCl}_{3}\right) \delta 39.8,52.3,57.4,59.3,127.0,128.3,128.9,139.6 ; \mathrm{MS} \mathrm{m} / \mathrm{z}: 326\left(\mathrm{M}^{+}\right)$; Anal. Calcd. $\mathrm{C}_{20} \mathrm{H}_{30} \mathrm{~N}_{4}$ : C, 73.58; H, 9.26; N, 17.16. Found: C, 73.10; H, 8.86; N, 16.82 .

5,8-Dibenzyl-1,5,8,12-tetraazadodecane (11b). According to the procedure used for the synthesis of $\mathbf{9 b}$, a $6 \mathrm{M} \mathrm{HBr}$ solution $(15 \mathrm{~mL})$ and a solution of $\mathbf{1 0 b}(5.0 \mathrm{~g}, 9.4 \mathrm{mmol})$ in ethanol $(50 \mathrm{~mL})$ were reacted to afford $11 \mathrm{~b}$ as a pale yellow oil $(3.32 \mathrm{~g}, 99 \%)$. ${ }^{1} \mathrm{H}-\mathrm{NMR}(200 \mathrm{MHz}$, $\left.\mathrm{CDCl}_{3}\right) \delta 1.53(4 \mathrm{H}, \mathrm{q}), 1.68(4 \mathrm{H}, \mathrm{s}), 2.40(4 \mathrm{H}, \mathrm{t}), 2.52(4 \mathrm{H}, \mathrm{s}), 2.62(4 \mathrm{H}, \mathrm{t}), 3.49(4 \mathrm{H}, \mathrm{s}), 7.21$ $(10 \mathrm{H}, \mathrm{m}) ;{ }^{13} \mathrm{C}-\mathrm{NMR}\left(50 \mathrm{MHz}, \mathrm{CDCl}_{3}\right) \delta 31.1,40.5,51.9,51.9,59.2,126.9,128.2,128.9,139.9$; MS m/z: $354\left(\mathrm{M}^{+}\right)$; Anal. Calcd. $\mathrm{C}_{22} \mathrm{H}_{34} \mathrm{~N}_{4}$ : C, 74.53; H, 9.67; N, 15.80. Found: C, 75.21; H, 9.97; N, 16.22.

1,4,7,10-Tetrabenzyl-1,4,7,10-tetraazadecane (12a). An excesss of sodium borohydride (1.51 $\mathrm{g}, 39.8 \mathrm{mmol})$ was added to a solution of $10 \mathrm{a}(5.0 \mathrm{~g}, 10 \mathrm{mmol})$ in ethanol $(50 \mathrm{~mL})$. The mixture was stirred under reflux for $3 \mathrm{~h}$, cooled to $0^{\circ} \mathrm{C}$ and $15 \mathrm{~mL}$ of water were added. The solution was evaporated and the residue was dissolved in the minimum amount of water. The aqueous phase was extracted 6 times with dichloromethane $(100 \mathrm{~mL})$. The combined organic solutions were dried over anhydrous $\mathrm{MgSO}_{4}$ and evaporated to give 12a as a pale yellow oil $(4.7 \mathrm{~g}, 93 \%) .{ }^{1} \mathrm{H}-$ NMR (200 MHz, CDCl $) \delta 2.15(2 \mathrm{H}, \mathrm{s}), 2.58(4 \mathrm{H}, \mathrm{s}), 2.62(4 \mathrm{H}, \mathrm{t}), 3.53(4 \mathrm{H}, \mathrm{s}), 3.63(4 \mathrm{H}, \mathrm{t})$, $3.69(4 \mathrm{H}, \mathrm{s}) ; 7.3(20 \mathrm{H}, \mathrm{m}) ;{ }^{13} \mathrm{C}-\mathrm{NMR}\left(50 \mathrm{MHz}, \mathrm{CDCl}_{3}\right) \delta 46.8,52.3,53,9,54,3,59.4,127.0$, 127.2, 128.3, 128.5, 128.9, 130.1, 139.7, 140.5; MS m/z: $507\left(\mathrm{M}^{+}+1\right)$; Anal. Calcd. $\mathrm{C}_{34} \mathrm{H}_{42} \mathrm{~N}_{4}$ : C, 80.59; H, 8.35; N, 11.06. Found: C, 80.66; H, 8.48; N, 10.87. 
1,5,8,12-Tetrabenzyl-1,5,8,12-tetraazadodecane (12b). According to the procedure used for the synthesis of 12a, sodium borohydride $(2.85 \mathrm{~g}, 75 \mathrm{mmol})$ and a solution of $10 \mathrm{~b}(10.0 \mathrm{~g}, 18$ $\mathrm{mmol})$ in ethanol $(100 \mathrm{~mL})$ were reacted to afford $\mathbf{1 2 b}$ as a pale yellow oil $(7.96 \mathrm{~g}, 79 \%) .{ }^{1} \mathrm{H}$ NMR $\left(200 \mathrm{MHz}, \mathrm{CDCl}_{3}\right) \delta 1.71(4 \mathrm{H}, \mathrm{q}), 2.21(2 \mathrm{H}, \mathrm{s}), 2.49(4 \mathrm{H}, \mathrm{t}), 2.58(4 \mathrm{H}, \mathrm{s}), 2.63(4 \mathrm{H}, \mathrm{t}), 3.55$ $(4 \mathrm{H}, \mathrm{s}), 3.75(4 \mathrm{H}, \mathrm{s}), 7.29(20 \mathrm{H}, \mathrm{m}) ;{ }^{13} \mathrm{C}-\mathrm{NMR}\left(50 \mathrm{MHz}, \mathrm{CDCl}_{3}\right) \delta 27.5,48.0,52.0,52.7,54.3$, 59.2, 126.9, 127.2, 128.2, 128.4, 128.9, 129.1, 139.9, 140.3; MS m/z: $535\left(\mathrm{M}^{+}+1\right)$; Anal. Calcd. $\mathrm{C}_{36} \mathrm{H}_{46} \mathrm{~N}_{4}:$ C, 80.85; H, 8.67; N, 10.48. Found: C, 81.38; H, 9.01; N, 10.51 .

1,4-Dibenzyl-1,4,7,10-tetraazacyclododecane-2,3-dione (18a). A solution of diethyloxalate $(4.48 \mathrm{~g}, 30 \mathrm{mmol})$ in anhydrous ethanol $(20 \mathrm{~mL})$ was added dropwise to a solution of $9 \mathrm{a}(10.0 \mathrm{~g}$, $30 \mathrm{mmol})$ in refluxing anhydrous ethanol $(250 \mathrm{~mL})$. The solution was stirred under reflux for 12 $\mathrm{h}$. The white solid formed was filtered and washed with ethanol to give 18a $(2.38 \mathrm{~g}, 20 \%) .{ }^{1} \mathrm{H}-$ NMR $\left(200 \mathrm{MHz}, \mathrm{CDCl}_{3}\right) \delta 1.80(2 \mathrm{H}, \mathrm{s}), 3.42(4 \mathrm{H}, \mathrm{t}), 3.52(4 \mathrm{H}, \mathrm{t}), 3.66(4 \mathrm{H}, \mathrm{s}), 4.62(4 \mathrm{H}, \mathrm{s})$, $7.26(10 \mathrm{H}, \mathrm{m}) ;{ }^{13} \mathrm{C}-\mathrm{NMR}\left(50 \mathrm{MHz}, \mathrm{CDCl}_{3}\right) \delta 43.3,43.8,44.0,50.6,128.4,129.0,135.6,139.5$, 160.1; IR (KBr, $\left.v_{\mathrm{C}=\mathrm{O}} \mathrm{cm}^{-1}\right)$ 1670; MS m/z: $381\left(\mathrm{M}^{+}+1\right)$; Anal. Calcd. $\mathrm{C}_{22} \mathrm{H}_{28} \mathrm{~N}_{4} \mathrm{O}_{2}$ : C, 69.45; H, 7.42; N, 14.72. Found: C, 68.70; H, 7.22; N, 14.37 .

1,4-Dibenzyl-1,4,8,11-tetraazacyclotetradecane-2,3-dione (18b). According to the procedure used for the synthesis of 18a, a solution of diethyloxalate $(4.13 \mathrm{~g}, 28 \mathrm{mmol})$ in anhydrous ethanol $(20 \mathrm{~mL})$ and a solution of $\mathbf{9 b}(10.0 \mathrm{~g}, 28 \mathrm{mmol})$ in anhydrous ethanol $(250 \mathrm{~mL})$ were reacted to afford $\mathbf{1 8 b}$ as a white solid $(3.42 \mathrm{~g}, 30 \%) .{ }^{1} \mathrm{H}-\mathrm{NMR}\left(200 \mathrm{MHz}, \mathrm{D}_{2} \mathrm{O}\right) \delta 1.65(4 \mathrm{H}, \mathrm{q})$, $3.32(4 \mathrm{H}, \mathrm{t}), 3.36(4 \mathrm{H}, \mathrm{t}), 3.62(4 \mathrm{H}, \mathrm{s}), 4.61(4 \mathrm{H}, \mathrm{s}), 7.32(10 \mathrm{H}, \mathrm{m}) ;{ }^{13} \mathrm{C}-\mathrm{NMR}\left(50 \mathrm{MHz}, \mathrm{D}_{2} \mathrm{O}\right) \delta$ 27.5, 43.2, 44.4, 44.8, 49.6, 128.3, 128.6, 129.0, 136.4, 161.1; IR (KBr, $\left.v_{\mathrm{C}=\mathrm{O}} \mathrm{cm}^{-1}\right) 1670$; MS m/z: $408\left(\mathrm{M}^{+}\right)$; Anal. Calcd. $\mathrm{C}_{24} \mathrm{H}_{32} \mathrm{~N}_{4} \mathrm{O}_{2}$ : C, 70.56; H, 7.89; N, 13.71. Found: C, 71.01; H, 7.71; $\mathrm{N}, 13.50$.

1,4-Bis[4'-aza-5'-phenylpentyl]-piperazine-2,3-dione (17b). The filtrate obtained after filtration of $\mathbf{1 8 b}$ in the previous synthesis was evaporated to afford $\mathbf{1 7 b}$ as a pale yellow oil (8.0 g, 70\%). ${ }^{1} \mathrm{H}-\mathrm{NMR}\left(200 \mathrm{MHz}, \mathrm{CDCl}_{3}\right) \delta 1.71(4 \mathrm{H}, \mathrm{q}), 1.96(2 \mathrm{H}, \mathrm{s}), 2.57(4 \mathrm{H}, \mathrm{t}), 3.33(4 \mathrm{H}, \mathrm{s})$, $3.45(4 \mathrm{H}, \mathrm{t}), 3.70(4 \mathrm{H}, \mathrm{s}), 7.24(10 \mathrm{H}, \mathrm{m}) ;{ }^{13} \mathrm{C}-\mathrm{NMR}\left(50 \mathrm{MHz}, \mathrm{CDCl}_{3}\right) \delta 27.5,44.6,45.4,46.0$, 54.0, 127.0, 128.3, 128.5, 140.2, 157.5; IR (KBr, $\left.v_{\mathrm{C}=\mathrm{O}} \mathrm{cm}^{-1}\right)$ 1670; MS m/z: $408\left(\mathrm{M}^{+}\right)$; Anal. Calcd. $\mathrm{C}_{24} \mathrm{H}_{32} \mathrm{~N}_{4} \mathrm{O}_{2}$ : C, 70.56; H, 7.89; N, 13.71. Found: C, 70.18; H, 7.38; N, 14.21.

1,4,7,10-Tetrabenzyl-1,4,7,10-tetraazacyclododecane-2,3-dione (20a). A solution of diethyloxalate $(1.15 \mathrm{~g}, 7.9 \mathrm{mmol})$ in anhydrous ethanol $(20 \mathrm{~mL})$ was added to a solution of 12a (4.0 g, $7.9 \mathrm{mmol})$ in anhydrous ethanol $(100 \mathrm{~mL})$. The solution was stirred under reflux for 6 days and then evaporated. The residual colorless oil was dissolved in the minimum amount of ethanol and diethylether was added. The white solid formed was filtered, washed with diethylether to afford 20a $(2.21 \mathrm{~g}, 50 \%)$. ${ }^{1} \mathrm{H}-\mathrm{NMR}\left(200 \mathrm{MHz}, \mathrm{CDCl}_{3}\right) \delta 2.50(4 \mathrm{H}, \mathrm{s}), 2.52(4 \mathrm{H}$, t), $2.92(4 \mathrm{H}, \mathrm{t}), 3.52(4 \mathrm{H}, \mathrm{s}), 3.96(4 \mathrm{H}, \mathrm{s}), 7.25(20 \mathrm{H}, \mathrm{m}) ;{ }^{13} \mathrm{C}-\mathrm{NMR}\left(50 \mathrm{MHz}, \mathrm{CDCl}_{3}\right) \delta 44.0$, 49.9, 50.9, 51.9, 57.3, 126.9, 127.1, 128.8, 129.1, 129.6, 130.2, 138.3, 138.7, 163.3; IR $(\mathrm{KBr}$, $\left.v_{\mathrm{C}=\mathrm{O}} \mathrm{cm}^{-1}\right)$ 1670; MS m/z: $560\left(\mathrm{M}^{+}\right)$; Anal. Calcd. $\mathrm{C}_{36} \mathrm{H}_{40} \mathrm{~N}_{4} \mathrm{O}_{2}:$ C, 77.11; H, 7.19; N, 9.99. Found: C, 77.82; H, 7.29; N, 10.07 . 
1,4,8,11-Tetrabenzyl-1,4,8,11-tetraazacyclotetradecane-2,3-dione (20b). According to the procedure used for the synthesis of 20a, a solution of diethyloxalate $(1.37 \mathrm{~g}, 9.3 \mathrm{mmol})$ in anhydrous ethanol $(20 \mathrm{~mL})$ and a solution of 12b $(5.0 \mathrm{~g}, 9.3 \mathrm{mmol})$ in anhydrous ethanol (100 $\mathrm{mL})$ were reacted to afford 20b as a white solid (4.13 g, 75\%). ${ }^{1} \mathrm{H}-\mathrm{NMR}\left(200 \mathrm{MHz}, \mathrm{CDCl}_{3}\right) \delta$ $1.81(4 \mathrm{H}, \mathrm{q}), 2.41(4 \mathrm{H}, \mathrm{t}), 2.42(4 \mathrm{H}, \mathrm{s}), 2.84(4 \mathrm{H}, \mathrm{t}), 3.56(4 \mathrm{H}, \mathrm{s}), 3.97(4 \mathrm{H}, \mathrm{s}), 7.24(20 \mathrm{H}, \mathrm{m})$; ${ }^{13} \mathrm{C}-\mathrm{NMR}\left(50 \mathrm{MHz}, \mathrm{CDCl}_{3}\right) \delta 23.9,45.4,50.9,51.1,51.4,59.3,127.1,127.2,128.3,128.9$, 130.0, 131.7, 138.9, 139.3, 161.1; IR (KBr, $\left.v_{\mathrm{C}=\mathrm{O}} \mathrm{cm}^{-1}\right)$ 1670; MS m/z: $588\left(\mathrm{M}^{+}\right)$; Anal. Calcd. $\mathrm{C}_{38} \mathrm{H}_{44} \mathrm{~N}_{4} \mathrm{O}_{2}$ : C, 77.52; H, 7.53; N, 9.52. Found: C, 76.29; H, 7.83; N, 9.01.

1,4-Dibenzyl-1,4,7,10-tetraazacyclododecane (19a). Under $\mathrm{Ar}$ atmosphere, a $1 \mathrm{M} \mathrm{BH} / \mathrm{THF}$ solution $(23.2 \mathrm{~mL}, 23.2 \mathrm{mmol})$ was added to a solution of 18a $(2.2 \mathrm{~g}, 5.8 \mathrm{mmol})$ in anhydrous THF $(60 \mathrm{~mL})$. The solution was heated at reflux for $12 \mathrm{~h}$. After cooling at $0^{\circ} \mathrm{C}$, a water/THF $(1 / 3)$ solution $(30 \mathrm{~mL})$ was added to quench excess borane. THF was evaporated, a $6 \mathrm{M} \mathrm{HCl}$ solution $(100 \mathrm{~mL})$ was added and the solution was heated at $100^{\circ} \mathrm{C}$ for $3 \mathrm{~h}$. After cooling at room temperature, $\mathrm{KOH}$ pellets were added $(\mathrm{pH}>11)$, and the solution was extracted 6 times with dichloromethane $(100 \mathrm{~mL})$. The combined organic solutions were dried over anhydrous $\mathrm{MgSO}_{4}$ and evaporated to afford 19a as a colorless oil (1.59 g, 78\%). ${ }^{1} \mathrm{H}-\mathrm{NMR}\left(200 \mathrm{MHz}, \mathrm{CDCl}_{3}\right) \delta 2.32$ $(4 \mathrm{H}, \mathrm{t}), 2.39(2 \mathrm{H}, \mathrm{s}), 2.60(4 \mathrm{H}, \mathrm{t}), 2.74(4 \mathrm{H}, \mathrm{s}), 3.01(4 \mathrm{H}, \mathrm{s}), 3.60(4 \mathrm{H}, \mathrm{s}), 7.20(10 \mathrm{H}, \mathrm{m}) ;{ }^{13} \mathrm{C}-$ NMR $\left(50 \mathrm{MHz}, \mathrm{CDCl}_{3}\right) \delta 45.6,48.1,51.3,52.0,57.8,128.1,128.5,129.3,140.5$; MS m/z: 352 $\left(\mathrm{M}^{+}\right)$; Anal. Calcd. $\mathrm{C}_{22} \mathrm{H}_{32} \mathrm{~N}_{4}$ : C, 74.96; H, 9.15; N, 15.89. Found: C, 74.21; H, 9.01; N, 15.21 .

1,4-Dibenzyl-1,4,8,11-tetraazacyclotetradecane (19b). According to the procedure used for the synthesis of 19a, a $1 \mathrm{M} \mathrm{BH}_{3} / \mathrm{THF}$ solution $(29.2 \mathrm{~mL}, 29.2 \mathrm{mmol})$ and a solution of $\mathbf{1 8 b}(3.0 \mathrm{~g}, 7.3$ $\mathrm{mmol})$ in anhydrous THF $(75 \mathrm{~mL})$ were reacted to afford $\mathbf{1 9 b}$ as a colorless oil $(2.44 \mathrm{~g}, 88 \%)$. ${ }^{1} \mathrm{H}-\mathrm{NMR}\left(200 \mathrm{MHz}, \mathrm{CDCl}_{3}\right) \delta 1.71(4 \mathrm{H}, \mathrm{q}), 2.01(2 \mathrm{H}, \mathrm{s}), 2.57(4 \mathrm{H}, \mathrm{t}), 2.59(4 \mathrm{H}, \mathrm{s}), 2.61(4 \mathrm{H}, \mathrm{t})$, $3.13(4 \mathrm{H}, \mathrm{s}), 3.50(4 \mathrm{H}, \mathrm{s}), 7.26(10 \mathrm{H}, \mathrm{m}) ;{ }^{13} \mathrm{C}-\mathrm{NMR}\left(50 \mathrm{MHz}, \mathrm{CDCl}_{3}\right) \delta$ 27.7. 49.6, 51.8, 52.7, 54.1, 60.9, 126.9, 128.2, 128.9, 139.6; MS m/z: $381\left(\mathrm{M}^{+}+1\right)$; Anal. Calcd. $\mathrm{C}_{24} \mathrm{H}_{36} \mathrm{~N}_{4}$ : C, 75.74; H, 9.53; N, 14.72. Found: C, 75.26; H, 9.45; N, 14.21 .

1,4,7,10-Tetrabenzyl-1,4,7,10-tetraazacyclododecane (21a). According to the procedure used for the synthesis of 19a, a $1 \mathrm{M} \mathrm{BH}_{3} / \mathrm{THF}$ solution $(14.4 \mathrm{~mL}, 14.4 \mathrm{mmol})$ and a solution of 20a $(2.0 \mathrm{~g}, 3.6 \mathrm{mmol})$ in anhydrous THF $(40 \mathrm{~mL})$ were reacted to afford 21a as a white solid $(1.12 \mathrm{~g}$, $59 \%$, M.p. $\left.=140-142^{\circ} \mathrm{C}\right) .{ }^{1} \mathrm{H}-\mathrm{NMR}\left(200 \mathrm{MHz}, \mathrm{CDCl}_{3}\right) \delta 2.71(16 \mathrm{H}, \mathrm{s}), 3.47(8 \mathrm{H}, \mathrm{s}), 7.2-7.4$ $(20 \mathrm{H}, \mathrm{m}) ;{ }^{13} \mathrm{C}-\mathrm{NMR}\left(50 \mathrm{MHz}, \mathrm{CDCl}_{3}\right) \delta 46.6$ 59.4, 126.2, 127.9, 128.8, 139.8; MS m/z: 533 $\left(\mathrm{M}^{+}+1\right)$; Anal. Calcd. $\mathrm{C}_{36} \mathrm{H}_{44} \mathrm{~N}_{4}$ : C, 81.16; H, 8.32; N, 10.52. Found: C, 80.42; H, 8.21; N, 10.08 . 1,4,8,11-Tetrabenzyl-1,4,8,11-tetraazacyclotetradecane (21b). According to the procedure used for the synthesis of 19a, a $1 \mathrm{M} \mathrm{BH}_{3} / \mathrm{THF}$ solution $(34.8 \mathrm{~mL}, 34.8 \mathrm{mmol})$ and a solution of 20b $(5.0 \mathrm{~g}, 8.7 \mathrm{mmol})$ in anhydrous THF $(80 \mathrm{~mL})$ were reacted to afford $21 \mathbf{b}$ as a white solid $\left(4.41 \mathrm{~g}, 89 \%\right.$, M.p. $\left.=152-154^{\circ} \mathrm{C}\right) .{ }^{1} \mathrm{H}-\mathrm{NMR}\left(200 \mathrm{MHz}, \mathrm{CDCl}_{3}\right) \delta 1.76(4 \mathrm{H}, \mathrm{q}), 2.54(8 \mathrm{H}, \mathrm{t}), 2.63$ $(8 \mathrm{H}, \mathrm{s}), 3.46(8 \mathrm{H}, \mathrm{s}), 7.26(20 \mathrm{H}, \mathrm{m}) ;{ }^{13} \mathrm{C}-\mathrm{NMR}\left(50 \mathrm{MHz}, \mathrm{CDCl}_{3}\right) \delta 23.8$ 50.5, 51.5, 59.5, 126.8 , 128.1, 129.0, 140.1; MS m/z: $561\left(\mathrm{M}^{+}+1\right)$; Anal. Calcd. $\mathrm{C}_{38} \mathrm{H}_{48} \mathrm{~N}_{4}$ : C, 81.38; H, 8.63; N, 9.99. Found: C, 82.12; H, 8.75; N, 10.38 . 
1,4,7,10-Tetraazacyclododecane (2a) via the 1,4-dibenzyl-1,4,7,10-tetraazacyclododecane (19a). Activated $\mathrm{Pd} / \mathrm{C}(1.0 \mathrm{~g})$ was added to a solution of 19a $(1.0 \mathrm{~g}, 2.8 \mathrm{mmol})$ in ethanol (40 $\mathrm{mL})$. The mixture was stirred under $\mathrm{H}_{2}$ atmosphere for $12 \mathrm{~h}$. After filtration over a celite plug, the solution was evaporated to give $2 \mathrm{a}$ (cyclen) as a white solid $(0.39 \mathrm{~g}, 81 \%) .{ }^{1} \mathrm{H}-\mathrm{NMR}(200$ $\left.\mathrm{MHz} \mathrm{CDCl}_{3}\right) \delta 2.12(4 \mathrm{H}, \mathrm{s}), 3.67(16 \mathrm{H}, \mathrm{s}) ;{ }^{13} \mathrm{C}-\mathrm{NMR}\left(50 \mathrm{MHz}, \mathrm{CDCl}_{3}\right) \delta$ 46.9; MS m/z: 173 $\left(\mathrm{M}^{+}+1\right)$; Anal. Calcd. $\mathrm{C}_{8} \mathrm{H}_{20} \mathrm{~N}_{4}$ : C, 55.78; H, 11.70; N, 32.52. Found: C, 55.02; H, 11.58; N, 31.97 .

1,4,8,11-tetraazacyclotetradecane (2b) via the 1,4-dibenzyl-1,4,8,11-tetraazacyclotetradecane (19b). According to the procedure used for the synthesis of $2 \mathbf{a}$, activated $\mathrm{Pd} / \mathrm{C}(3.0 \mathrm{~g})$ and a solution of $\mathbf{1 9 b}(4.0 \mathrm{~g}, 10.5 \mathrm{mmol})$ in ethanol $(100 \mathrm{~mL})$ were reacted to afford $\mathbf{2 b}$ (cyclam) as a white solid (1.93 $\mathrm{g}, 92 \%)$.

1,2-Bis[(3-benzyl-2-phenyl)-1,3-imidazolidyl]ethane (22a). According to the procedure used for the synthesis of 4, sodium borohydride $(0.43 \mathrm{~g}, 11.4 \mathrm{mmol})$ and a solution of 7a $(1.0 \mathrm{~g}, 2.85$ $\mathrm{mmol})$ in ethanol $(20 \mathrm{~mL})$ were reacted to afford a colorless oil. The white solid formed upon addition of ethanol $(15 \mathrm{~mL})$ to this oil was filtrated and washed with cold ethanol to give 22a $\left(0.71 \mathrm{~g}, 50 \%\right.$, M.p. $\left.=182^{\circ} \mathrm{C}\right)$ which can be recrystallized from dichloromethane. The oil isolated upon evaporation of the filtrate was identified as 9a. ${ }^{1} \mathrm{H}-\mathrm{NMR}\left(500 \mathrm{MHz}, \mathrm{C}_{6} \mathrm{D}_{6}\right) \delta 2.11-2.45(6 \mathrm{H}$, m), 2.61-2.85 (2H, m), 2.80-3.35 (6H, m), $3.51(2 \mathrm{H}, \mathrm{d}), 3.75(2 \mathrm{H}, \mathrm{d}), 7.0-7.7(20 \mathrm{H}, \mathrm{m}) ;{ }^{13} \mathrm{C}-$ NMR $\left(125 \mathrm{MHz}, \mathrm{C}_{6} \mathrm{D}_{6}\right) \delta 52.0,52.2,52.3,58.1,89.7,127.0,128.4,128.6,128.7,128.9,129.9$, 140.1, 141.9; MS m/z: $503\left(\mathrm{M}^{+}+1\right)$; Anal. Calcd. $\mathrm{C}_{34} \mathrm{H}_{38} \mathrm{~N}_{4}$ : C, 81.24; H, 7.62; N, 11.15. Found: C, 80.92; H, 7.78; N, 11.00 .

1,2-Bis[(3-benzyl-2-phenyl)-1,3-pyrimidinyl]ethane (22b). According to the procedure used for the synthesis of 18a, a solution of diethyloxalate $(0.66 \mathrm{~g}, 4.5 \mathrm{mmol})$ in anhydrous ethanol (5 $\mathrm{mL})$ and a solution of $\mathbf{8 b}(2.0 \mathrm{~g}, 4.5 \mathrm{mmol})$ in anhydrous ethanol $(25 \mathrm{~mL})$ were reacted to afford 22b as a white solid (1.18 g, 50\%) which can be recrystallized in acetone/dichloromethane (50/50). The oil isolated upon avaporation of the filtrate was identified as $\mathbf{1 7 b}$. ${ }^{1} \mathrm{H}-\mathrm{NMR}$ (500 $\left.\mathrm{MHz}, \mathrm{C}_{6} \mathrm{D}_{6}\right) \delta 1.21(4 \mathrm{H}, \mathrm{m}), 1.80-2.00(4 \mathrm{H}, \mathrm{m}), 2.00-2.10(2 \mathrm{H}, \mathrm{m}), 2.62(2 \mathrm{H}, \mathrm{d}), 2.76(2 \mathrm{H}, \mathrm{d})$, 2.83-2.86 (2H, m), $2.97(2 \mathrm{H}, \mathrm{m}), 3.55(2 \mathrm{H}, \mathrm{s}), 3.71(2 \mathrm{H}, \mathrm{d}), 7.0-7.7(20 \mathrm{H}, \mathrm{m}) ;{ }^{13} \mathrm{C}-\mathrm{NMR}(125$ $\left.\mathrm{MHz}, \mathrm{C}_{6} \mathrm{D}_{6}\right) \delta 24.9,51.7,52.4,52.6,58.7,88.7,127.0,128.4,128.5,129.1,130.2,130.3,140.4$, 142.9; MS m/z: $530\left(\mathrm{M}^{+}\right)$; Anal. Calcd. $\mathrm{C}_{36} \mathrm{H}_{42} \mathrm{~N}_{4}$ : C, 81.47; H, 7.98; N, 10.56. Found: C, 81.07; H, 7.99; N, 10.53 .

\section{Acknowledgements}

This work was supported through grants from the Conseil Régional de Bourgogne, Air Liquide SA, the CNRS and the French Ministry for Research. 


\section{References}

1. For examples, see: (a) Meyer, M.; Dahaoui-Gindrey, V.; Lecomte, C.; Guilard, R. Coord. Chem. Rev. 1998, 180, 1313. (b) Wainwright, K. P. Coord. Chem. Rev. 1997, 166, 35. (c) Izatt, R. M.; Pawlak, K.; Bradshaw, J. S.; Bruening, R. L. Chem. Rev. 1995, 95, 2529. (d) Haines, R. I. Rev. Inorg. Chem. 2001, 21, 165.

2. (a) Barbette, F.; Rascalou, F.; Chollet, H.; Babouhot, J. L.; Denat, F.; Guilard, R. Anal. Chem. Acta 2004, 179. (b) Cuenot, F.; Meyer, M.; Bucaille, A.; Guilard, R. J. Mol. Liq. 2005, 1118, 89.

3. Dubois, G.; Tripier, R.; Brandès, S.; Denat, F.; Guilard, R. J. Mater. Chem. 2002, 12, 2255.

4. (a) Reichenbach-Klinke, R.; König, B. J. Chem. Soc. Dalton Trans. 2002, 121. (b) Kimura, E. Tetrahedron 1992, 48, 6175.

5. (a) Bernhardt, P. V.; Moore, E. G. Aust. J. Chem. 2003, 56, 239. (b) Fabbrizzi, L.; Licchelli, M.; Pallavicini, P. Acc. Chem. Res. 1999, 32, 846.

6. (a) Merbach, A. E.; Toth, E.; Eds The Chemistry of Contrast Agents in Medical Magnetic Resonance Imaging, John Wiley \& Sons: New York, 2001. (b) Liang, X.; Sadler, P. J. Chem. Soc. Rev. 2004, 33, 246.

7. For examples, see: (a) Denat, F.; Brandès, S.; Guilard, R. Synlett 2000, 561 and references therein. (b) Liu, S.; Edwards, D. S. Bioconjugate Chem. 2001, 12, 7.

8. (a) Boschetti, F.; Denat, F.; Espinosa, E.; Tabard, A.; Dory, Y.; Guilard, R. J. Org. Chem. 2005, 70, 7042. (b) Boschetti, F.; Denat, F.; Espinosa, E.; Guilard, R. Chem. Commun. 2002, 312. (c) Boschetti, F.; Denat, F.; Espinosa, E.; Lagrange, J.-M.; Guilard, R. Chem. Commun. 2004, 588. (d) Hervé, G.; Bernard, H.; Le Bris, N.; Yaouanc, J. J.; Handel, H. Tetrahedron Lett. 1998, 39, 6861. (e) Sandnes, R. W.; Vasilevskis, J.; Undheim, K.; Gacek, M. WO 9628432, 1996.

9. Tripier, R.; Siri, O.; Rabiet, F.; Denat, F.; Guilard, R. Tetrahedron Lett. 1999, 40, 79.

10. (a) White, V. A.; Long, N. J.; Robertson, N. Org. Biomol. Chem. 2005, 3, 4268. (b) Cronin, L.; McGregor, P. A.; Parsons, S.; Teat, S.; Gould, R. O.; White, V. A.; Long, N. J.; Robertson, N. Inorg. Chem. 2004, 43, 8023.

11. Tripier, R.; Denat, F.; Guilard, R.; Ledon, H. FR2810035, 2000.

12. Isaksson, R.; Liljefors, T.; Sandström, J. J. Chem. Res. (S) 1981, 43; J. Chem. Res. (M) 1981, 0664.

13. Çetinkaya, E.; Hitchcock, P. B.; Jasim, H. A.; Lappert, M. F.; Spyropoulos, K. J. Chem. Soc., Perkin Trans. I 1992, 561.

14. (a) Trokowski, R.; Zhang, S.; Sherry, A. D. Bioconjugate Chem. 2004, 15, 1431. (b) Guilard, R.; Meunier, I.; Jean, C.; Boisselier-Cocolios, B. EP 0427595, 1991. (c) Li, Z.; Undheim, K. Acta Chem. Scand. 1998, 52, 1247.

15. Duhamel, L. Aminals in Chemistry of Amino, Nitroso, Nitro Compounds and their Derivatives, Ch. 20, pp 849-907, Patai, S.; Ed., Wiley: Chichester, 1982.

16. North, A. C. T.; Phillips, D. C.; Mathews, F. S. Acta Cryst. 1968, A24, 351. 
17. DENZO software (Otwinowski, Z. and Minor, W. (1997), Methods Enzymol., $276,307$.

18. SIR92 - A program for crystal structure solution. Altomare, A.; Cascarano G.; Giacovazzo C.; Guagliardi A. J. Appl. Crystallogr. 1993, 26, 343.

19. SHELXL97 program. Sheldrick, G. M. Program for the Refinement of Crystal Structures. University of Göttingen, Germany, 1997.

20. OpenMolEN, Interactive Intelligent Structure solution. Nonius B. V., Delft, The Netherlands, 1997. 